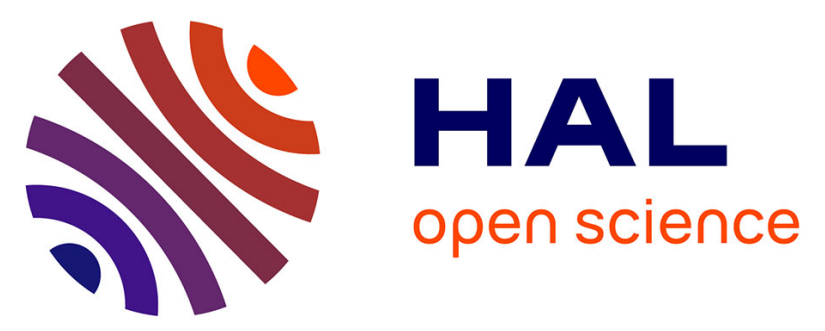

\title{
Holocene land cover dynamics in the Curuai Floodplain inferred from lacustrine biomarkers
}

Renata Zocatelli, Patricia Moreira-Turcq, Jérémy Jacob, Renato Campello

Cordeiro, Mohammed Boussafir, Claude Le Milbeau, Marcelo Bernardes, Bruno Turcq

\section{To cite this version:}

Renata Zocatelli, Patricia Moreira-Turcq, Jérémy Jacob, Renato Campello Cordeiro, Mohammed Boussafir, et al.. Holocene land cover dynamics in the Curuai Floodplain inferred from lacustrine biomarkers. Palaeogeography, Palaeoclimatology, Palaeoecology, 2016, 443, pp.237-248. 10.1016/j.palaeo.2015.11.046 . insu-01240341

\section{HAL Id: insu-01240341 \\ https://hal-insu.archives-ouvertes.fr/insu-01240341}

Submitted on 11 Dec 2015

HAL is a multi-disciplinary open access archive for the deposit and dissemination of scientific research documents, whether they are published or not. The documents may come from teaching and research institutions in France or abroad, or from public or private research centers.
L'archive ouverte pluridisciplinaire HAL, est destinée au dépôt et à la diffusion de documents scientifiques de niveau recherche, publiés ou non, émanant des établissements d'enseignement et de recherche français ou étrangers, des laboratoires publics ou privés. 


\section{Accepted Manuscript}

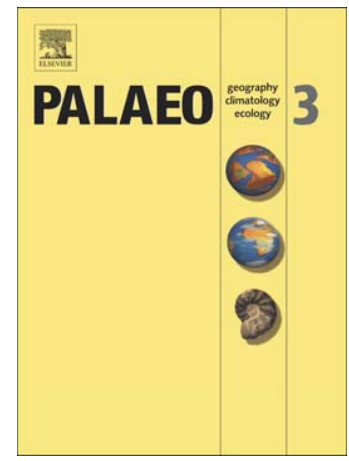

PII:

S0031-0182(15)00716-6

DOI: $\quad$ doi: $10.1016 /$ j.palaeo.2015.11.046

Reference: $\quad$ PALAEO 7598

To appear in: $\quad$ Palaeogeography, Palaeoclimatology, Palaeoecology

Received date: 6 May 2015

Revised date: 23 November 2015

Accepted date: 29 November 2015

Please cite this article as: Zocatelli, R., Moreira-Turcq, P., Jacob, J., Cordeiro, R.C., Boussafir, M., Le Milbeau, C., Bernardes, M., Turcq, B., HOLOCENE LAND COVER DYNAMICS IN THE CURUAI FLOODPLAIN INFERRED FROM LACUSTRINE BIOMARKERS, Palaeogeography, Palaeoclimatology, Palaeoecology (2015), doi: 10.1016/j.palaeo.2015.11.046

This is a PDF file of an unedited manuscript that has been accepted for publication. As a service to our customers we are providing this early version of the manuscript. The manuscript will undergo copyediting, typesetting, and review of the resulting proof before it is published in its final form. Please note that during the production process errors may be discovered which could affect the content, and all legal disclaimers that apply to the journal pertain. 


\section{HOLOCENE LAND COVER DYNAMICS IN THE CURUAI FLOODPLAIN INFERRED}

\section{FROM LACUSTRINE BIOMARKERS}

Zocatelli, R. ${ }^{1,2,3}$, Moreira-Turcq, P. ${ }^{4}$, Jacob, J. ${ }^{1,2,3}$, Cordeiro, R.C. ${ }^{5}$, Boussafir, M. ${ }^{1,2,3}$, Le Milbeau, C. ${ }^{1,2,3}$, Bernardes, M. ${ }^{5}$, Turcq, B. ${ }^{4}$

${ }^{1}$ Université d'Orléans, Institut des Sciences de la Terre d'Orléans (ISTO), UMR 7327, 45071 Orléans, France

${ }^{2}$ CNRS/INSU, ISTO, UMR 7327, 45071 Orléans, France

${ }^{3}$ BRGM, ISTO, UMR 7327, BP 36009, 45060 Orléans, France

${ }^{4}$ Institut de Recherche pour le Développement (IRD) - LMTG; 32, Avenue Henri Varagnat, 93143, Bondy Cedex, France.

${ }^{5}$ Universidade Federal Fluminense, Morro do Valonguinho s/n, Departamento de Geoquímica Niterói, Rio de Janeiro, Brasil.

Abstract: This study on Curuai Floodplain (Central Amazonia) sediments (last 5600 cal yr BP) focused in Rock-Eval [RE; hydrogen (HI) and oxygen (OI) indices, Tmax, S2 curve and TpS2], organic petrography and molecular biomarkers [n-alkanes, hopanes, pentacyclic triterpene methyl ethers (PTMEs) and derivatives of pentacyclic triterpenes such as des-Alupane and aromatic derivatives] analyses. Between 5600 and $5100 \mathrm{cal} \mathrm{yr} \mathrm{BP}$, the environment was waterlogged and dominated by emersed plants (Paq 0.27-0.38). The influence of the Amazon River was low. Terrestrial vs aquatic ratio (T/A, 0.8), CPI values (3-4) and high contents of PTME (0.22-1.54 $\mu \mathrm{g} / \mathrm{g}$ sed) and aromatics $(21-53 \mu \mathrm{g} / \mathrm{g}$ sed) indicated a strong contribution of terrestrial material and anoxic OM deposition conditions. Between 5100 and 5000 cal yr BP more humid conditions due to heavier rainfalls were observed. Early in this period, terrestrial biomarker contents $(253 \mu \mathrm{g} / \mathrm{g}$ sed of aromatics, Paq 0.17) increased due to input of watershed erosion material. This provoked a rapid burial and good preservation of terrestrial OM (CPI 3-4.5). From 5000 cal yr BP a strong sedimentation of carbonate minerals (OI $\sim 1600 \mathrm{mg} \mathrm{CO} \mathrm{CO}^{-1}$ ) masked the $\mathrm{OM}$ signal and affecting $\mathrm{RE}$ parameters. Paq ( 0.18), T/A ratio $(\sim 0.4)$ and the decrease of $\mathrm{C}_{31 \alpha \beta} / \mathrm{C}_{31 \beta \beta}$ hopanes (1.18) indicate increasing aquatic conditions up to 2700 cal yr BP. CPI ratio $(\sim 1.2)$ and degraded phytoclasts suggest intense degradation during transport to the sedimentation location. The PTMEs results showed that, from $3000 \mathrm{yr}$ cal BP, the Poaceae genuses were different from those found at the bottom (middle-Holocene), suggesting a change of vegetation. The last 600 cal yr BP were marked by the seasonal influence of the Amazon River; during periods of low water level, the organic petrography and CPI values ( 1.0) evidenced OM degradation and the return of rather drier conditions.

Keywords: organic matter, Rock Eval; organic petrography; Amazon River.

Corresponding author e-mail address: renata.zocatelli@univ-orleans.fr (R. Zocatelli). 


\section{Introduction}

Floodplains along the Amazon River have been studied to improve the understanding of the Amazonian carbon cycle and to determine the evolution of organic matter (OM) deposited in the sediments (e.g., Aufdenkampe et al., 2011; Moreira-Turcq et al., 2013). The Amazon River drains a huge amount of OM that originates from the tropical forest located in its basin (Moreira-Turcq et al., 2013; Zocatelli et al., 2013). Amazonian floodplains play an important role in the production, storage and export of OM for downstream ecosystems. As a result, OM stored in sedimentary deposits are composed of (i) multiple sources from the Amazon drainage basin (both terrestrial and aquatic, ex. flooded forest), (ii) material from the immediate surroundings (marginal input, ex. macrophytes and periphyton) and (iii) autochthonous material produced in the floodplain (phytoplankton). The study of sedimentary archives can help unravelling changes in the hydrological and biogeochemical cycles. These changes can affect abiotic and biotic processes occurring in both floodplains and the surrounding flooded soils (Richey et al., 1990; Seyler and Boaventura, 2003).

In Central Amazonia, the Curuai Floodplain is the most extensive flooded region spreading over an area of $3500 \mathrm{~km}^{2}$ (about $13 \%$ of the total flooded area, Maurice-Bourgoin et al., 2007). Some recent studies discussed the control of Amazon River on the geochemistry of Curuai Floodplain sediments (effect on stratification of suspended sediments, Roddaz et al., 2014) and on the floodplain hydrology (Bonnet et al., 2008) and paleohydrology (Moreira et al., 2012). Simultaneously, other studies conducted in Curuai Floodplain have investigated the $\mathrm{OM}$ sources and preservation from molecular biomarkers analyses in a sedimentary succession recording the last century (Zocatelli et al., 2013), in water column (Mortillaro et al., 2011) and in surface sediments (Zocatelli et al., 2011; Sobrinho et al., 2015). The composition of OM buried in Curuai Floodplain is influenced by the material input dynamics from the Amazon River, the multiple sources from the Amazon drainage basin (see above) and quality of organic carbon in surface sediments. These parameters that control the spatial 
and temporal variability of $\mathrm{OM}$ composition stored in Curuai Floodplain remain unrecognized.

In organic geochemistry, several studies showed a link between molecular biomarker imprints stored in lacustrine sediments and the evolutionion of past environments and ecosystems, including the past land cover of catchment areas (e.g. Wakeham et al., 1980; Cranwell, 1984; Innes et al., 1997; Ficken et al., 2000; Bardy et al., 2009; Nakamura et al., 2010; Lavrieux et al., 2011; Le Milbeau et al., 2013; Zocatelli et al., 2010, 2012a, 2012b, 2013). This is possible because molecular biomarkers stored in soils and sediments are directly linked to the current overlying vegetation (e.g. Corbet, 1980; Killops et al., 1995; Van Bergen et al., 1997; Bull et al., 1998). Molecular biomarkers are compounds preserved intact or slightly modified in natural archives, which structures allow unequivocal identification of the biological source (e.g. Van Bergen et al., 1997; Simoneit, 2004; Killops and Killops, 2004; Lavrieux et al., 2011). Then, molecular biomarkers stored in lacustrine sediments reflect the combined effect of original source inputs and selective diagenesis during and after sedimentation. Lipid extraction of lacustrine sediments yields hydrocarbons such as $n$-alkanes and cyclic compounds such as pentacyclic triterpenes that could have specific biological sources. Also, lipid alterations can be used as proxies for the general processes affecting the lacustrine OM (Meyers and Ishiwatari, 1993). These characteristics make $n$-alkanes and pentacyclic triterpenes particularly valuable for the determination of OM sources and preservation (e.g. Ho and Meyers, 1994; Andersson et al., 2012).

In an effort to complement previous studies, in addition to gaining information on past landscape, a sedimentary sequence (TA14) retrieved from the Curuai Floodplain previously described and dated by Moreira et al. (2012) that covers the last 5,600 years was analyzed. From an integrated organic geochemistry approach using several organic proxies such as Rock-Eval parameters, organic petrography and lipid biomarker analysis, this study aims at 
distinguishing the sources and the preservation state of OM buried in sediments identifying the past land cover of the Curuai Floodplain catchment.

\section{Materials and methods}

\subsection{Study area}

The Curuai floodplain is located between $1^{\circ} 50^{\prime} \mathrm{S}-02^{\circ} 17^{\prime} \mathrm{S}$ and $55^{\circ} 00^{\prime} \mathrm{W}-56^{\circ} 05^{\prime} \mathrm{W}$ on the southern margin of the Amazon River, $850 \mathrm{~km}$ from the estuary (Fig. 1). Water and sediment exchanges between the floodplain and the Amazon River are controlled by the mainstream hydrology, local precipitation regimes and the geomorphological characteristics of the channels and lakes. The flooded area ranges between $575 \mathrm{~km}^{2}$ and $2090 \mathrm{~km}^{2}$, as water levels vary between $4.2 \mathrm{~m}$ and $10.3 \mathrm{~m}$ (Bonnet et al., 2008). The maximum floodable area is delimited by the boundary between "terra firme" (southwards, Fig. 1) and the Amazon River. Terra firme forest is not flooded and is mostly covered by evergreen forest. During the low water season, the floodplain landscape mainly consists of savannahs, low vegetation and alluvial forest (RADAMBRASIL project, 1976).

\subsection{Core presentation and sample selection}

The TA14 core, of $270 \mathrm{~cm}$ length, was collected in the Santa Ninha lake at $2^{\circ} 07^{\prime} 31^{\prime \prime} \mathrm{S} /$ $55^{\circ} 49^{\prime} 29^{\prime \prime} \mathrm{W}$ using a vibracorer and immediately cooled. In the laboratory, the core was opened, described and sub-sampled every around $1 \mathrm{~cm}$. Lithological units described previously by Moreira et al. (2012) were determined in function of several criteria such as color, granulometry and the presence of visible plant remains (Fig. 2a). A robust chronology for this sequence, obtained from 14 radiocarbon dates, was established and covers the last 5,600 years (Moreira et al., 2012). ${ }^{14} \mathrm{C}$ measurements were performed with an Accelerator Mass Spectrometer (AMS) system based on a 3MV Pelletron from National Electrostatics Corporation (NEC, Middleton, Wisconsin, USA) at Laboratoire de Mesures du ${ }^{14} \mathrm{C}$ (LMC14, 
Artémis), Saclay, France. The calibrated ages were calculated using the CALIB 5.0.2 software available at http://radiocarbon.pa.qub.ac.uk/calib (Stuiver and Reimer 1993). The probability peak of the calibration curve in each 2 -sigma $(2 \sigma)$ interval was considered to calculate the age model, based on cubic spline interpolations to the calibrated ${ }^{14} \mathrm{C}$ ages. The TA14 core covers a time span of approximately 5600 cal yr BP and is composed of five sedimentary units with different sedimentation rates (Fig. 2a): unit V (UV, $270 \mathrm{~cm}$ to $199 \mathrm{~cm}$; 5600 to 5100 cal yr BP), unit IV (UIV, $199 \mathrm{~cm}$ to $165 \mathrm{~cm} ; 5100$ to $5000 \mathrm{cal} \mathrm{yr} \mathrm{BP);} \mathrm{unit} \mathrm{III}$ (UIII, $165 \mathrm{~cm}$ to $125 \mathrm{~cm} ; 5000$ to $4000 \mathrm{cal} \mathrm{yr} \mathrm{BP}$ ); unit II (UII, $125 \mathrm{~cm}$ to $34 \mathrm{~cm}$; 4000 to $2300 \mathrm{cal}$ yr BP) and unit I (UI, $34 \mathrm{~cm}$ until the top, $600 \mathrm{cal}$ yr BP to the present day).

\subsection{Rock-Eval analysis}

Bulk organic geochemistry of sediments was determined by Rock-Eval pyrolysis (RE). RE was carried out on $100 \mathrm{mg}$ powdered dry sediment with a "Turbo" Rock-Eval 6 pyrolyzer. The IFP 160000 standard was used to calibrate the measurements. The pyrolysis program was as follows: $2 \mathrm{~min}$ at $200{ }^{\circ} \mathrm{C}$, raised to $650{ }^{\circ} \mathrm{C}$ at $30{ }^{\circ} \mathrm{C} \cdot \mathrm{min}^{-1}$. The oxidation phase (air stream) began with an isothermal stage at $400{ }^{\circ} \mathrm{C}$, which was then increased to 650 ${ }^{\circ} \mathrm{C}\left(30{ }^{\circ} \mathrm{C} \cdot \mathrm{min}^{-1}\right)$ and held for $5 \mathrm{~min}$ at this temperature. Here, we focused on the hydrogen index (HI, mg HC g ${ }^{-1} \mathrm{TOC}$ ), the oxygen index (OI, mg $\left.\mathrm{CO}_{2} \mathrm{~g}^{-1} \mathrm{TOC}\right)$, Tmax $\left({ }^{\circ} \mathrm{C}\right.$; temperature at which the hydrocarbons maximum resulting from kerogen cracking occurs) the $\mathrm{S} 2$ curve (amount of hydrocarbonaceous compounds that escapes from the sample during thermal cracking, expressed in $\mathrm{mg} \mathrm{HC})$ and the $\mathrm{TpS} 2\left({ }^{\circ} \mathrm{C}\right.$; temperature corresponding to the maximum thermal cracking). The standard deviation of RE parameters was estimated as: $\mathrm{HI}: \pm 3 \%$; OI: $\pm 3 \%$; Tmax and $\mathrm{TpS} 2: \pm 3{ }^{\circ} \mathrm{C}$. RE parameters can give quantitative $\mathrm{OM}$ information as well as information about their origin and preservation state. Espitalié et al. (1985) identified three main types of OM: (i) Type I is attributed to a hydrogen-rich and oxygen-depleted lacustrine algal OM; (ii) Type II corresponds to mixed OM in lacustrine sites; (iii) Type III is typical of 
an oxygen-rich and hydrogen-poor OM derived from lignin-rich vascular plant material. Based on the lithological features, forty-four samples were selected for Rock-Eval analyses.

\subsection{Organic petrography analysis}

Organic petrography was based on the optical identification of OM after dissolution of the mineral matrix by acidic treatments $(\mathrm{HCl}$ and $\mathrm{HF})$ of about $1 \mathrm{~g}$ of sediment. The $\mathrm{OM}$ concentrates were diluted in $5 \mathrm{ml}$ of $\mathrm{H}_{2} \mathrm{O}$, and an aliquot of $5 \mu \mathrm{l}$ was used for the thin plate assembly. LEICA DMR XP microscope was used to observe the organic residues under natural transmitted light. Over 1000 microscopic fields were counted to estimate the relative proportions of each class of organic fraction after obtaining standard deviation values $\leq 1 \%$ for each class.

\subsection{Biomarkers extraction, separation and GC-MS analyses}

Lipids were extracted from ca. $1 \mathrm{~g}$ of sediment by ASE 200 with $\mathrm{CH}_{2} \mathrm{Cl}_{2}: \mathrm{CH}_{3} \mathrm{OH}$ (9:1 v/v). Total extract was fractionated in two steps: First, neutral, acidic and polar compounds were separated on silica bonded with aminopropyl groups according to Jacob et al. (2005). Then, neutral compounds were further separated on activated silica into i) aliphatic hydrocarbons, ii) aromatic hydrocarbons and iii) ethers fractions using a sequence of solvents of increasing polarity. Fractions were analyzed by gas chromatography-mass spectrometry (GC-MS) with a TRACE gas chromatograph coupled to a Polaris-GCQ mass spectrometer. The gas chromatograph was fitted with a Rtx-5MS column $(30 \mathrm{~m}, 0.25 \mathrm{~mm}$ i.d., $0.25 \mu \mathrm{m}$ film thickness) with $5 \mathrm{~m}$ of guard column. The GC operating conditions were: temperature held at $40{ }^{\circ} \mathrm{C}$ for $1 \mathrm{~min}$, then increased from 40 to $120{ }^{\circ} \mathrm{C}$ at $30{ }^{\circ} \mathrm{C} \min ^{-1}$, from 120 to $300{ }^{\circ} \mathrm{C}$ at $3{ }^{\circ} \mathrm{C}$ $\min ^{-1}$, with a final isothermal hold at $300{ }^{\circ} \mathrm{C}$ over $30 \mathrm{~min}$. The sample was injected splitless, with the injector temperature set at $280{ }^{\circ} \mathrm{C}$. Helium was the carrier gas. The mass spectrometer was operated in the electron ionization (EI) mode at $70 \mathrm{eV}$ ionization energy and 
scanned from $\mathrm{m} / \mathrm{z} 50$ to 600 . Compound identification was performed by interpretation of fragmentation patterns, relative retention times and comparison with reported mass spectra in the literature. Due to possible coelutions, concentrations were estimated by measuring the areas of their peaks on ion specific chromatograms. Concentrations were estimated after calculating a correction factor between the peak area on the ion specific chromatogram and the peak area on the Total Ion Current (TIC).

\section{Results}

\subsection{Rock-Eval analysis}

In UV, OI was low: between 104 and $138 \mathrm{mg} \mathrm{CO} \cdot \mathrm{g}^{-1}$ TOC, and HI was high: between 138 and $284 \mathrm{mg} \mathrm{HC} . \mathrm{g}^{-1}$ TOC (Fig. 2). In UIV, OI values remained low: between 104 and 138 mg CO $2 . g^{-1}$ TOC, whereas HI values increased from 217 to $448 \mathrm{mg} \mathrm{HC} . \mathrm{g}^{-1}$ TOC (Fig. 2). In UV, the S2 curve was unimodal, whereas in UIV the S2 curve was broader than in UV and bimodal with two TpS2 values (382 and $414{ }^{\circ} \mathrm{C}$ ). Rock-Eval parameters in UIII differed from those in the other units: OI reached $1600 \mathrm{mg} \mathrm{CO} \cdot \mathrm{g}^{-1}$ TOC whereas HI values decreased towards the top of the core (Fig. 2b). The unimodal S2 curve exhibits TPS2 values around 450 ${ }^{\circ} \mathrm{C}$. The top of the core (UII and UI) showed higher OI and smaller HI values than those at the base (Fig. 2). In these units OI ranged between 210 and $394 \mathrm{mg} \mathrm{CO}_{2} \cdot \mathrm{g}^{-1}$ TOC and HI values between 74 and $188 \mathrm{mg} \mathrm{HC} . \mathrm{g}^{-1}$ TOC. In UI and UII the shapes of the S2 curves were distinct. Although in both cases UII and UI had a bimodal and dissymmetric S2 curve, the TpS2 in UII was $\sim 275{ }^{\circ} \mathrm{C}$ whereas in UI TpS2 was $\sim 463{ }^{\circ} \mathrm{C}$ (Fig. 2c).

\subsection{Organic petrography}

Particles were identified and grouped in different classes: Phytoclasts, which include lignocellulosic debris (LC), membranes and cuticles $(\mathrm{Mb}+\mathrm{Cut})$; other particles assigned to algal $\mathrm{OM}$; charcoal; and amorphous $\mathrm{OM}(\mathrm{rAOM}=$ reddish $\mathrm{AOM}$ and $\mathrm{FAOM}=$ floconous 
AOM; Zocatelli et al., 2012b). Mb+Cut originated mainly from aquatic macrophytes whose tissue had settled in the water column and had become incorporated into the sediment (Turcq et al., 2002). rAOM derived from soils in the watershed (Tyson, 1995) and FAOM are considered as degraded material of algal or palustrine origin had been altered in the aquatic environment.

In UV, gelified phytoclast particles (Mb+Cut and LC) was dominant, accounting for $75 \%$ of total particles (Fig. 3). rAOM reached the highest proportion (around 20\%) whereas FAOM and algal particles exhibited the lowest proportions of the core $(<1 \%)$. In UIV, rAOM decreased slightly whereas FAOM increased toward the top of the core and algal particles contribution remained low. Coarse FAOM particles $(400 \mu \mathrm{m})$ were well preserved. In UIV, the organic particles were composed mainly of gelified LC. At the base of UIII, phytoclasts, which represented $50 \%$ of total particles, had low average size $(50 \mu \mathrm{m}$; Fig. 3). Toward the top of the core, phytoclasts decreased whereas FAOM were the most abundant particles in the amorphous class. In UIII, all classes of particles were more degraded than in the previous units. The average size of LC decreased to $20 \mu \mathrm{m}$ in UII. At the base of UII, FAOM and algal particles (aquatic) represented $\sim 50 \%$ of total particles and increased progressively towards the top of the unit. In UI the abundance of aquatic particles decreased toward the top of the core whereas phytoclast particles, extensively oxidized, increased.

In UV, gelified phytoclasts ( $\mathrm{Mb}+\mathrm{Cut}$ and $\mathrm{LC})$ was dominant, accounting for $75 \%$ of total particles (Fig. 3). rAOM reached the highest proportion (around 20\%), whereas FAOM and algal particles exhibited the lowest proportions of the core $(<1 \%)$. In UIV, rAOM decreased slightly, whereas FAOM increased toward the top of the core, and algal particles contribution remained low. Coarse FAOM particles $(400 \mu \mathrm{m})$ presented homogeneous the external contour and internal tissues identifiable thus characterizing the well preserved of OM. In UIV, the organic particles were mainly composed of gelified LC. At the base of UIII, phytoclasts, which represented $50 \%$ of total particles, had low average size $(50 \mu \mathrm{m}$; Fig. 3). Toward the 
top of the core, phytoclasts decreased whereas FAOM were the most abundant particles of the amorphous class. In UIII, all classes of particles were more degraded than in previous units. The average size of LC decreased to $20 \mu \mathrm{m}$ in UII. At the base of UII, FAOM and algal particles (aquatic) represented $\sim 50 \%$ of total particles and increased progressively towards the top of the unit. In UI, the abundance of aquatic particles decreased toward the top of the core whereas phytoclast particles, extensively oxidized, increased. From the class of particles identified in Curuai sediment samples, a terrestrial/aquatic ratio (T/A) was determined through the following equation: $\mathrm{T} / \mathrm{A}=(\mathrm{rAOM}+\mathrm{LC}+\mathrm{Mb}+\mathrm{Cut}) /(\mathrm{rAOM}+\mathrm{LC}+\mathrm{Mb}+\mathrm{Cut}+$ FAOM + algal). T/A ratio will be discussed in Section 4.3.

\subsection{Identification of molecular imprints}

Overall, forty-two compounds were identified using GC-MS. The main characteristics of the compounds are summarized in Table 1: $n$-alkanes, pentacyclic triterpene derivatives (aromatics and one des-A-triterpene), hopanes and pentacyclic triterpene methyl ethers (PTMEs). We focused on aliphatic, aromatic and ethers fractions and did not analyse the acid and alcohol fractions. Steranes and aromatic steranes were not detected in our samples.

$n$-alkanes - Sixteen $n$-alkanes ranging from $n$ - $\mathrm{C}_{18}$ to $n$ - $\mathrm{C}_{33}$ were found (Tables 1 and 2; Fig. 4). $n$-Alkanes were detected on the from $\mathrm{m} / \mathrm{z}=57+71+85$ ion specific chromatogram. The Carbon Preference Index (CPI; Bray and Evans, 1961) was determined with the following equation: $\mathrm{CPI}=2\left(\right.$ odd $n-\mathrm{C}_{23}$ to $\left.n-\mathrm{C}_{31}\right) /\left(\right.$ even $n-\mathrm{C}_{22}$ to $n-\mathrm{C}_{30}+$ even $n-\mathrm{C}_{24}$ to $\left.n-\mathrm{C}_{32}\right)$. This ratio is considered both as a good indicator of the potential contribution of land plants to the bulk OM (Peters et al., 2005; Van Dongen et al., 2006), and as a good indicator of OM preservation (Xie et al., 2004; Zheng et al., 2007; Jansen and Nierop, 2009; Zhou et al., 2010, Garel et al., 2013). Unlike CPI values, odd/even ratio takes into account all homologous found in the samples (odd/even ratio $=\sum$ odd n-Alkanes/ $/$ eve n-Alkanes). The Paq expresses 
the relative proportion of mid-chain n-alkanes $\left(n-\mathrm{C}_{23}, n-\mathrm{C}_{25}\right)$ and was calculated as follows: $\mathrm{Paq}=\left(n-\mathrm{C}_{23}+n-\mathrm{C}_{25}\right) /\left(n-\mathrm{C}_{23}+n-\mathrm{C}_{25}+n-\mathrm{C}_{29}+n-\mathrm{C}_{31}\right)$ (Ficken et al., 2000).

Derivatives of pentacyclic triterpenes - Twelve compounds were identified as derivatives of pentacyclic triterpenes (Table 1; Fig. 4). All the compounds are pentacyclic, except compounds 1, 2, 3 and 4 that are tetracyclic. Compound $1\left(\mathrm{C}_{24} \mathrm{H}_{42}\right)$ was detected in the aliphatic hydrocarbon fraction. Its mass spectrum displayed $M_{+}$at 330 and intense $\mathrm{m} / \mathrm{z}$ at 163, 149, 191, 177, 206 and 330. It was identified as 10ß-des-A-lupane (Corbet, 1980; Jacob et al., 2007; Table 1). The other derivatives were detected in the aromatic fraction. The mass spectra of compounds 2, 3 and $4\left(\mathrm{C}_{22} \mathrm{H}_{28}\right)$ display $\mathrm{M}+$ at 292 and intense fragments at 207, 193 and 123. They were identified as des-A-dinoroleana-5,7,9,11,13-pentaene, des-Adinorursa-5,7,9,11,13-pentaene and des-A-dinorlupa-5,7,9,11,13-pentaene, respectively (Trendel et al., 1989; Huang et al., 2013). Compounds 5 to 8 are monoaromatic pentacyclic derivatives. Compounds 5 (dinor-oleana(ursa)-1,3,5(10),12-tetrane) and 6 (dinoroleana(ursa)-1,3,5(10),13(18)-tetrane) exhibited a molecular ion at $\mathrm{M}^{+} 376\left(\mathrm{C}_{28} \mathrm{H}_{40}\right)$ and compounds 4 and 5 at $\mathrm{M}^{+} 378\left(\mathrm{C}_{28} \mathrm{H}_{42}\right)$. Compounds 5, 6, 7 and 8 showed intense ions at $\mathrm{m} / \mathrm{z}$ $145,157,158,170$ and 172 whereas compounds 7 and 8 only showed an intense ion at $\mathrm{m} / \mathrm{z}$ 145 and minor ions at $\mathrm{m} / \mathrm{z} 157$ and 172 . Compounds 7 and 8 were identified as dinoroleana(ursa)-1,3,5(10)triene and dinor-lupa-1,3,5 (10)-triene, respectively. Compounds 9 $(24,25,26,27$-tetranoroleana-1,3,5(10), 6,8,11,13-heptaene), $10 \quad(24,25,26,27$-tetranorursa1,3,5(10), 6,8,11,13-heptaene) and 11 (24,25,26,27-tetranorlupa-1,3,5(10), 6,8,11,13heptaene) exhibited molecular ions at $\mathrm{M}^{+} 342$ and are interpreted as triaromatic derivatives (Table 1). Compound 12 (24,25,26,27,28-pentanoroleana-1,3,5(10), 6,8,11,13,15,17heptaene) identified by comparison with Killops et al. (1995) was the only tetra-aromatic pentacyclic triterpene derivative found in the Curuai Floodplain sediments. The ratio between pentacyclic aromatic derivatives and the des-A-triterpenes was determined with the following equation: $5 \mathrm{C} / \mathrm{des}-\mathrm{A}=(\Sigma \text { conc.5 to 12 })^{*} 100 /\left(\sum\right.$ conc.2 to 12 $)$. To summarize the variations and 
estimate the aromatization degree of pentacyclic aromatic compounds, the following ratio was calculated: $5 \mathrm{C}$ Aromat. degree $=\left[\left(\sum\right.\right.$ conc.5 to 8$) * 1+(\Sigma$ conc.9 to 11$) * 3+\left(\right.$ conc. $\left.\left._{12}\right) * 4\right] * 100 /$ (Sconc.2 to 12$)$.

Hopanes - Nine hopanes ranging from $C_{27}$ to $C_{31}$ were detected in TA14 samples (Table 1; Fig. 4). These compounds showed an intense ion at m/z 191 and minor ions at m/z 177 and 205. $\mathrm{C}_{27}$ (17 $\alpha$ trisnorhopane and $17 \beta$ trisnorhopane; 10 and 11 , respectively), $\mathrm{C}_{29}(17 \alpha, 21 \beta$ norhopane; $17 \beta, 21 \alpha$ norhopane and $17 \beta, 21 \beta$ norhopane; 15,16 and 18 , respectively), $\mathrm{C}_{30}$ $\left(17 \alpha, 21 \beta\right.$ hopane and $17 \beta, 21 \beta$ hopane; 17 and 20 respectively) and $C_{31}(17 \alpha, 21 \beta$ homohopane and $17 \beta, 21 \beta$ homohopane, 19 and 21 , respectively) compounds were detected. The ratio between $C_{31 \alpha \beta}$ hopane and the $C_{31 \beta \beta}\left(C_{31 \alpha \beta} / C_{31 \beta \beta}\right.$; Innes et al., 1997) was determined with the following equation: $\mathrm{C}_{31 \alpha \beta} / \mathrm{C}_{31 \beta \beta}$ Hopanes = conc. $16 /$ conc. 18 .

Pentacyclic triterpene methyl ethers - Five PTMEs, all characterized by $\mathrm{M}^{+}$at 440 were identified in the ether fraction and separated in two groups: group $\mathrm{I}(\mathrm{m} / \mathrm{z}=$ $218+203+189$, compounds 22, 23 and 24) and group II $(\mathrm{m} / \mathrm{z}=241+273+393)$. Compound 22 presented intense ions at m/z 218, 204, 189 316, 301, 284 and 269 typical for crusgallin (Jacob et al., 2005). Compounds 23 and 24 that showed ions at m/z 189, 203 and 218 were identified as $\beta$-amyrin ME and $\alpha$-amyrin ME. $\beta$-amyrin ME was also confirmed from authentic standard. Compounds 25 and 26 displayed very similar mass spectra, with significant fragments at $\mathrm{m} / \mathrm{z} 393,287,273,255$ and 241 . The identification of these compounds as arundoin and cylindrin, respectively, was confirmed by injections of authentic standards and respective retention times.

\subsection{Distribution of biomarkers imprints and evolution in TA14 profile}

The dominant compounds in the different units of the core varied between $n$-alkanes, hopanes and pentacyclic triterpene derivatives (Table 2 and 3). The total abundance of $n$ alkanes ranged from 0.80 to $8.3 \mu \mathrm{g} / \mathrm{g}$ sed, making them the most abundant compounds in UI, 
UII and UIII. In all samples, the distribution of $n$-alkanes was dominated by long chain homologues $\left(>n-\mathrm{C}_{25}\right)$. However, in the TA14 profile the major $n$-alkane homologues and the odd-over-even predominance degree varied between the samples (Table 2). In UV the lowermost sample showed an $n$-alkane distribution maximized at $n-\mathrm{C}_{25}, n-\mathrm{C}_{27}$ and $n$ - $\mathrm{C}_{29}$. In UIV, the most abundant $n$-alkane was $n-\mathrm{C}_{29}$, followed by $n-\mathrm{C}_{27}$ and $n-\mathrm{C}_{31}$. In UIII, $n-\mathrm{C}_{29}$ and $n$ - $\mathrm{C}_{27}$ were dominant. In UII and UI, the major $n$-alkanes varied from one to another sample (Table 2). High values of odd-even ratio and CPI were observed in samples of UIV and UV (odd/even > 2.5; CPI > 3.0), whereas in UII and UIII, CPI and odd/even ratio showed values close to 1 . In UI, CPI values ranged between 2 and 3. Paq values ranged between 0.27 and 0.62 in UIII and UV samples, whereas Paq values of UII samples ranged between 0.41 and 0.47. Samples of UIV showed Paq values ranging from 0.15 to 0.18 , whereas the two samples of UI displayed Paq values of 0.33 .

High amounts of pentacyclic triterpene derivatives were found in UIV and UV (up to 250 $\mu \mathrm{g} . \mathrm{g}^{-1}$ sed, sample 196; Table 3). From UV to UIII, the pentacyclic triterpene derivative contents decreased suddenly to zero. At the same time, the 5C/des-A, which reached $99 \%$ in UV, decreased to $52.8 \%$ at the base of UIII. In UV the aromatization degree was around 1.12 whereas it increased in UIV (1.32-1.87). Aromatics were absent in UII and were again detected in low amounts in UI. The low 5C/des-A values ( $60 \%)$ evidenced the high diversity of aromatics compounds but, nevertheless, a slight dominance of compounds with preserved A-ring. Among these aromatics, compound 12 (tetra-aromatic triterpene derivative) was detected in high contents and thus is responsible for the high values of the aromatization degree ( 4; Table 3). Hopane contents varied between 0.36 and $10.55 \mu \mathrm{g} / \mathrm{g}$ sed. In UV, hopane contents were between 0.68 and $0.69 \mu \mathrm{g} / \mathrm{g}$ sed. In UIV, hopane reached $10.55 \mu \mathrm{g} / \mathrm{g}$ sed (sample 182; Table 3). The lowest contents were found in UIII and UII (Table 3). In UI, the hopane contents increased again, reaching $4.57 \mu \mathrm{g} / \mathrm{g}$ sed close to the top of the core (sample 26; Table 3). The highest $\mathrm{C}_{31 \alpha \beta} / \mathrm{C}_{31 \beta \beta}$ hopane ratio (compound $19 /$ compound 21) was 
detected in UIV, and then decreased towards the top of the core (Table 3). In UI, UII and UV the $\mathrm{C}_{31 \alpha \beta} / \mathrm{C}_{31 \beta \beta}$ hopane ratios were below 1.0, whereas in UIV and UIII the ratio was higher than 1.0. PTME contents ranged from 0.0 to $2.1 \mu \mathrm{g} / \mathrm{g}$ sed (Table 3). High contents of group II (cylindrin and arundoin) were measured at the base of the core (UIV and UV). Conversely, compounds of group I (crusgalin, $\beta$-amyrin-ME and $\alpha$-amyrin-ME) were more concentrated at the top of the core (Table 3).

\section{Discussion}

\subsection{Characterization of lacustrine profile from bulk analyses}

The Rock-Eval data suggested three major events corresponding to the base (UV and UIV), the center (UIII) and the top of the core (UII and UI). Rock-Eval parameters (HI, OI, $\mathrm{TpS} 2$ and S2 curve) indicated that the origin of the OM buried in the units differed. These parameters also indicated that between UV and UIII, environmental changes occurred gradually. The HI vs OI diagram (Pseudo van-Krevelen, Fig. 5) showed that samples from units UV to UIV clustered in the same field whereas HI vs Tmax diagram showed a slight separation between these units. In fact, there was a trend over time from $\mathrm{OM}$ of terrestrial origin at the beginning (Type III, UV) to a mixture of OM from terrestrial and algal sources originating from a lacustrine environment (Type II, UIV). In UIII unimodal S2 curve, stretching the $\mathrm{TpS} 2$ around $450{ }^{\circ} \mathrm{C}$, (Fig. 2c), indicating that the $\mathrm{OM}$ was predominantly from a single source. Also, as indicated in the HI vs OI and HI vs Tmax diagrams, samples of UIII contained a significant mineral fraction that affects the OI values (OM artifact, Baudin et al., 2015). The mineral composition will be discussed below, in section 4.3. The upper part of the core (UII and UI) showed higher OI and lower HI values than at the base. HI vs OI diagram shows that UII and UI belong to Type III OM (terrestrial). However, they can be differentiated by their S2 curves and by HI vs Tmax diagram. UII samples had lower Tmax values than UI samples (close to $250^{\circ} \mathrm{C}$ ). So, UII and UI had a bimodal and dissymmetric S2 
curve, indicating that sedimented OM came from distinct sources (Simonneau et al., 2013) or possesses two different states of degradation. Previous studies have shown that mathematical deconvolution of the S2 curve into elementary signals can bring some insight into $\mathrm{OM}$ composition. According to the interpretation of Disnar et al. (2003) and Sebag et al. (2006) S2 curve from UII samples would be related to resistant 'bio-macromolecules' typical of fresh plant material (Tpeak less than $360{ }^{\circ} \mathrm{C}$ ) and slightly more thermal resistant biopolymers such as lignin and cellulose (Tpeak $360-370{ }^{\circ} \mathrm{C}$ ). In contrast, the S2 curve from UI samples would be related to more stable and transformed compounds such as humic substances.

\subsection{Biomarkers fingerprint - indicators of organic matter composition in Curuai sediments}

Lipids in a sedimentary sequence provide useful information about the sources and preservation of OM. Within the range of lipid structures, some are less likely to be altered by diagenesis than others. Comparisons between easily altered and less easily altered biomarkers can help distinguishing diagenetic changes from source changes (Meyers and Ishiwatari, 1993; Peters et al., 2005; van Dongen et al., 2006; Lavrieux et al., 2012; Garel et al., 2013; Huang et al., 2015). According to Killops and Killops (2005), compounds containing oxygen functional groups predominate among the lipid components at the start of the diagenesis. They undergo defunctionalization processes leading at the end to the formation of hydrocarbons, either saturated or aromatic. Note that the potential differences in depositional conditions are dependent of several factors, such as the nature and quantity of organic matter inputs, the redox state within the water column and sediments from the basin. The lipids stocked in sediments are subjected to diagenesis that lead to the loss of many compounds. Short chain molecules are preferentially degraded as they go through the water column. $n$ Alkanes with longer chain length are less degradable than are their shorter chain-length counterparts and can preserve evidence of source changes. The selective microbial utilization of short chains can affects the $n$-alkanes distributions in lake sediments. 
In the TA14 core, $n$-alkanes were dominated by homologues ranging from $n$ - $\mathrm{C}_{25}$ to $n$ - $\mathrm{C}_{33}$, suggesting a terrestrial vascular plant origin $\left(>n-\mathrm{C}_{20}\right.$; Eglinton et al., 1962). These $n$-alkanes are thought to derive from epicuticular waxes whereas the $n$-alkanes ranging from $n-\mathrm{C}_{15}$ to $n$ $\mathrm{C}_{19}$ indicate algal input (Eglinton and Hamilton, 1963; Tissot and Welte, 1984). The $n$-alkane CPI is generally interpreted in terms of the origin (Bray and Evans, 1961; Eglinton et al., 1962) and has also been used to assess the degree of preservation of alkyl biomarkers in sedimentary sequences (Xie et al., 2004; Zheng et al., 2007; Jansen and Nierop, 2009; Zhou et al., 2010). This is due to the strong $n$-alkanes odd predominance in fresh plant OM (Rieley et al., 1991). Thus, odd/even ratio is similar to a CPI ratio, although odd/even ratio takes into account all detected homologous. $n$-Alkanes from the epicuticular wax in vascular plants have high CPI values that tend to diminish during microbial degradation, while $n$-alkanes in bacteria and algae commonly have low CPI values (Gelpi et al., 1970; Cranwell, 1980; Andersson and Meyers, 2012). Preserved terrestrial OM displays CPI values between 3 and 10 (as in UIV and UV) whereas CPI values between 1 and 3 are the first signs of early degradation (as in UI). Values close to 1 may indicate a greater input from microorganisms and/or recycled organic matter (as in UII and UIII; Bray and Evans, 1961; Stefanova et al., 1995).

In a study of the current vegetation around the tropical African lakes, Paq ratio was proposed by Ficken et al. (2000) to estimate the contribution of terrestrial, emersed plants, submerged and floating macrophytes. According to them, Paq ranges from 0.4 to 1 for floating and submersed plants, whereas the Paq of emersed plants ranges from 0.1 to 0.4 , and the Paq of terrestrial plants ranges from 0.01 to 0.23 . Afterwards, several studies used this ratio to estimate current and past hydrological conditions and reconstruct the past environments (Zheng et al., 2007; Zhou et al., 2010; Andersson et al., 2011; Garel et al., 2013; Zocatelli et al., 2014). Here, Paq values were used to estimate different vegetal contributions through time and then to evaluate the aquatic macrophyte production in the 
flooded area. For the Curuai sequence, Paq values indicative of emersed plants were obtained from samples of UI, UIII and UV, whereas Paq of floating and submerged plants were registered in UII. Samples of UIV showed Paq values close to Paq values found for terrestrial plants (between 0.15 and 0.18 ).

At the base of the TA14 profile (UIV and UV), pentacyclic triterpene derivatives were the major lipids detected, principally the monoaromatic triterpenoids (compounds 8, 9, 10 and 11). Previous studies detected aromatic derivatives of pentacyclic triterpenes in soils and sediments (Wakeham et al., 1980; Hazai et al., 1986; Hazai, 1992; Jaffé et al., 1995; Jacob et al., 2007). Jaffé et al. (1995) reported the occurrence of mono- to tetraaromatic triterpenoids in flooded rain forest, whereas Laflamme and Hites (1979) reported their occurrence in recent sediments from the Amazon basin. These aromatic triterpenoids are intermediates in a series of postulated pathways for progressive aromatization of angiosperm pentacyclic triterpenoids (Tan and Heit, 1981, Nakamura et al., 2010) from the A-ring to the D-ring going from monoto tetraaromatic compounds (Trendel, 1985; Trendel et al., 1989) which promotes the formation of a vast number of compounds. Jaffé et al. (1995) and Jacob et al. (2007) suggested that the aromatic derivatives of pentacyclic triterpenes wtih preserved A-ring only occurs in anoxic conditions, indicating an anaerobic environment. In the TA14 core, high values of the $5 \mathrm{C} / \mathrm{des}-\mathrm{A}$ values were observed in $\mathrm{UV}$, potentially evidencing anoxic conditions in water column and sediments (Table 3 and Fig. 4). In UIV 5C/des-A values tend to decrease from the base to the top of unit and are absent in UIII. These values indicate that anoxic conditions were mostly present at the base of the core and then decreased over time.

For the Curuai sequence, the aromatization degree (5C Aromat. degree) of pentacyclic triterpenes derivatives was calculated from mono-, tri- and tetraaromatic compounds (compounds 5 to 12). Previous study realized by Huang et al. (2013) evidenced that triaromatic and tetraaromatic oleanenes may be affected mainly by paleohydrological conditions and partially by paleotemperature in the Dajiuhu peat deposit. In fact, Huang et al. 
(2013) suggested that during dry or warm intervals, highly aromatized products such as tetraaromatic oleanenes dominate over their triaromatic analogs, and, in contrast, triaromatic oleanenes dominate during wet or cold intervals. However, the specific mechanisms and controlling factors leading to the formation of the compounds remain to be identified. In TA14 core 5C Aromat. degree indicates that pentacyclic triterpene derivatives stored in UV sediments are less aromatized than in UIV sediments. In the top of TA14 core, the higher Aromat. degree values result from the high abundance of compound 12, a tetraaromatic triterpene derivative.

Like vascular plant pentacyclic triterpenes, hopanes are one of the most abundant group of organic molecules and can be subjected to a wide range of early diagenetic reactions in recent sediments (Farrimond et al., 2003 and references therein). Their biological precursors include bacteriohopanetetrol and similar compounds, which are synthesized by diverse groups of bacteria (Rohmer et al., 1984). Farrimond et al. (2003) showed that modern sediments are generally dominated by $\beta, \beta$ isomers, whilst ancient sediments/rocks dominated by $\alpha, \beta$ isomers (Love et al., 1995; Bishop et al., 1998). Innes et al. (1997) suggested that $\alpha, \beta$ isomers in lake sediments derived from soils and/or peat within the catchment area. In the TA14 profile, the increase in the $\mathrm{C}_{31 \alpha \beta} / \mathrm{C}_{31 \beta \beta}$ ratio was interpreted as an indicator of $\mathrm{OM}$ origin; high values being used as an input of terrestrial material supplied by soil erosion.

The PTMEs detected in the TA14 core were previously detected in soils and sediment profiles (Jacob et al., 2005; Bardy et al., 2009; Zocatelli et al., 2010). Most of the PTME plant sources are Poaceae. As such, these molecules are considered specific of the Gramineae species. These molecules are reputed to be stable in the early stages of diagenesis (Jacob et al., 2005). Thus, the molecular diversity observed in the sediments could reflect the diversity of past plant communities. Between the top and bottom of the TA14 core, the PTME distribution differs, indicating a possible change in Poaceae types that covered the Curuai 
catchment. However, due to the large number of species in the Amazon ecosystem, it is not possible to establish more precise chemotaxonomical relationships.

\subsection{Evolution of the depositional environment}

The sedimentary record of the Curuai Floodplain reveals the paleoenvironmental events resulting from relations between soils, vegetation, hydrology and sedimentation. These relations were evaluated from the abundance, the nature and/or the preservation of the sedimented OM. Ultimately, it allows us distinguishing floodplain dynamics during the last 5600 cal yr BP. The period between 5600 and 5100 cal yr BP Rock-Eval parameters (OM Type III; HI vs OI and HI vs Tmax diagrams) and high CPI values indicated a strong contribution of terrestrial materials. These data indicated that the sedimented $\mathrm{OM}$ is well preserved due to possible limited transport. This period was marked by a great diversity of pentacyclic triterpenes (aromatic derivatives of pentacyclic terpenes, des-A-lupane, hopanes and PTMEs, Fig. 6, Table 3). High values of pentacyclic trierpene derivatives could be explained by the rapid deposition of fresh vascular plant debris forming monoaromatic derivatives (Fig. 6). According to Jaffé and Hausmann (1995) the anoxic deposition environment as found in Lake Valencia could explain the early formation of these compounds. The detection of high proportions of gelified phytoclasts found in organic petrography corroborated the anoxic conditions hypothesis (Garel et al., 2013). Moreover, a high T/A ratio (terrestrial vs aquatic), Thus, we suggest that in this unit sediments were stored in a waterlogged environment dominated by emersed plants, as indicated by high Paq values. At the same time, PTME biomarkers of group II corroborated the waterlogged environment hypothesis (Fig. 6). These compounds (arundoin and cylindrin) were detected in 11 Graminea species (Jacob et al., 2005). Some of these plants may be higher than $1.5 \mathrm{~m}$ and survive waterlogged environments such as those found in floodplain forests currently observed in the Amazon basin. All the data indicate that in this phase the Amazon River had a reduced 
influence, thus favoring the development of waterlogged vegetation. This interpretation is corroborated by slight horizontal laminations found in the TA14 profile suggesting that the floodplain sediment has not been significantly disturbed since deposition (Aalto et al., 2003; Moreira et al., 2012). Based on the current system and given the assumption of no change in topography (tectonic) during the Holocene, the water column during this period was lower than the current level (lower than $4 \mathrm{~m})$.

The period between 5100 and 5000 cal yr BP (Unit IV) was marked by an abrupt increase in the sedimentation rate: 100 years were recorded in $30 \mathrm{~cm}$. RE parameters (Fig. $2 \mathrm{~b}$ and Fig. 5) showed that OM was of Type II, indicating more aquatic conditions than during the previous phase. Paq values were between terrestrial and emersed plants probably indicating an aquatic environment still influenced by terrestrial inputs. The rise in the water column was attested by the appearance of FAOM leading to a decrease in the T/A ratio (Fig. 6). At the beginning of this period, terrestrial biomarker increased due to lixiviation of the catchment before definitive soil flooding. The $\mathrm{C}_{31 \alpha \beta} / \mathrm{C}_{31 \beta \beta}$ hopane ratio and $5 \mathrm{C}$ Aromat. degree increased, suggesting an input of soil-derived hopanes (Innes et al., 1997) accompanied by aromatic derivatives of pentacyclic triterpenes. These inputs indicated higher erosion in the watershed certainly due to heavier rainfall, suggesting a more humid phase. After this first stage of water floodplain filling, all the parameters that characterize terrestrial conditions decreased (total of pentacyclic triterpenes derivatives, PTMEs and T/A ratio), indicating that the water column continued to rise. Assuming that, and as currently observed, periods of high water supply coarser-grained suspended load from the Amazon River (Maurice-Bourgoin et al., 2007; Moreira-Turcq et al., 2004). The mineral input suspended would represent the majority of the deposited material, thereby masking the OM signal. This hypothesis is corroborated by high CPI, the observation of preserved phytoclasts and the increase of sedimentation rate that provide a favorable OM preservation due to rapid sediment burial. 
During the period between 5000 and 2300 cal yr BP, two units (UIII and UII) were clearly differentiated from the rest of the core from Rock-Eval results (Fig. 2 and 5). In UIII (5000 to $4000 \mathrm{cal}$ yr BP) OI values reached $1600 \mathrm{mg} \mathrm{CO}_{2} \mathrm{~g}^{-1} \mathrm{TOC}$ and $\mathrm{TpS} 2$ was around 460 ${ }^{\circ} \mathrm{C}$. The elevated OI values are commonly associated with rocks containing significant quantities of the carbonate minerals (calcite, dolomite and siderite; Katz, 1983). Katz (1983) examined the effects of the presence of carbonate minerals on the OI values in carbonate rocks and concluded that the occurrence of carbonate minerals interferes with the OI calculation. Here, we examined the effects of the possible presence of carbonate minerals to explain the anomalous OI values in UIII sediments. Samples were decarbonated by treatment with $\mathrm{HC} 1$ and the degassing was observed. Then, decarbonated samples were analyzed by Rock-Eval pyrolysis. OI values obtained were closed to those of UI and UII samples (between 300 and $400 \mathrm{mg} \mathrm{CO}_{2} \mathrm{~g}^{-1}$ TOC). Jacob et al. (2004) and Marchand et al. (2008) showed that anomalous OI values similar to our data resulted from $\mathrm{CO}_{2}$ released at low temperatures indicating carbonate precipitation in these layers $\left(\mathrm{TpS} 2 \mathrm{FeCO}_{3}=450{ }^{\circ} \mathrm{C}\right)$. In addition, the study site is covered by lateritic soils rich in iron (Fe; Melfi et al., 1996). According to Marchand et al. (2008) in an anoxic environment with available metals such as the derived lateritic soils, OM degradation promotes carbonate precipitation, which could explain the siderite deposition and the anomalous OI values. Cardoso (2004) reported siderite precipitation in Lake Caçó and emphasized that siderite formation is dependent on $\mathrm{Fe}$ availability and the water residence time in the system. Thus, all the factors responsible for the formation and sedimentation of siderite were present, ie: sediments rich in OM, iron availability and high water residence time in Curuai Floodplain.

Unlike Rock-Eval results, the distinction between UIII and UII from biomarkers and organic petrography is less marked. These parameters indicate that the transition from UIII to UII took place progressively. The Paq, T/A and $C_{31 \alpha \beta} / C_{31 \beta \beta}$ hopanes ratios showed the progressive increase of floodplain water level. From $4500 \mathrm{cal} \mathrm{yr}$ BP to $2700 \mathrm{cal} \mathrm{yr}$ BP the 
relative increase of $n-\mathrm{C}_{25}$ homologue indicates an increase in aquatic vegetation inputs related to floating and submerged plants (Ficken et al., 2000). Simultaneously, due to low predominance odd-over-even homologues (odd/even ratio 1), low CPI values were obtained (CPI 1). This, combined to the small and degraded phytoclasts (20 $\mu \mathrm{m}$ per particle), evidenced the poor preservation conditions during deposition or strong degradation experienced during transport to the sedimentation location.

At $2710 \mathrm{yr}$ cal BP, group I PTMEs reaches the highest concentrations found in the profile (Fig. 5d). These compounds are known to be specific biomarkers of Poaceae family (Jacob et al., 2005 references therein). In Amazonian Basin Poaceae is composed of more than 100 genuses and thousands of species (LSBF, 2010) that are the potential sources of PTMEs. However, due to the huge number of plants and the current lack of phytochemical studies, it was not possible to identify more precisely the source of group I PTME. Nonetheless, the difference in PTME imprints between the base and the top of the core suggests a change in the species composition of the Poaceae family after a 2000 years period during which aquatic conditions dominated. The sharp contact at $34 \mathrm{~cm}$, between 2300 and $600 \mathrm{cal} \mathrm{yr} \mathrm{BP}$, corresponds to a break in sedimentation, interpreted by Moreira et al. (2012) as the consequence of a strong erosive event due to the strong influence of the Amazon River. However, according to Roddaz et al. (2014) the sediments analyzed post-600 years BP have similar chemical and isotopic characteristics to those before the erosive event indicating that that hydrodynamic and climatic changes that have affected the Santa Nina Lake had no influence on the chemical composition of the sediments and did not provoke a drainage reorganization during the last 5600 years.

The top $34 \mathrm{~cm}$ of the core (the last $600 \mathrm{cal} \mathrm{yr} \mathrm{BP}$ ) registered the increase of and the T/A ratio and the return of group I of PTMEs and the pentacyclic trierpene derivatives contents in the sedimentary sequence (Fig. 6). Although this phase was still mainly aquatic, group I PTMEs indicated a progressive return of terrestrial conditions in the Curuai Floodplain. 
Among the pentacyclic and tetracyclic derivatives detected, a tetraaromatic with a preserved A-ring was the most abundant. This strong aromatization of pentacyclic triterpenes derivatives indicated an advanced diagenesis of OM. Other indicators such as the Rock-Eval parameters, CPI values, as well the 5C/des-A values indicate that $\mathrm{OM}$ was strongly degraded, possibly as a result of long transportation from the Amazonian catchment. The same characteristics are observed today in surface sediments of the Curuai Floodplain (e.g. Moreira-Turcq et al., 2005; Zocatelli et al., 2013).

\section{Conclusions}

In the Curuai Floodplain, the combination of organic petrography, Rock-Eval parameters and molecular biomarkers in the sediment profile has made it possible to characterize the OM origin from contrasted events that are the result of the interactions between climate, Amazon hydrology and the terrestrial and lacustrine environments. Between 5600 and $5100 \mathrm{cal} \mathrm{yr}$ BP, the catchment was covered by a floodplain forest (vegetation adapted to a waterlogged environment). Sedimented OM was composed of fresh vascular plant debris rapidly buried in anoxic conditions allowing good OM preservation. In this period, the reduced seasonal impact of the Amazon River on the floodplain ecosystem favored the development of terrestrial vegetation. Based on the current system, the water column was lower than the current level. Between 5100 and $5000 \mathrm{cal}$ yr BP an abrupt increase in the sedimentation rate due to Amazon River floods provoked rapid burial and good preservation of sedimented OM. At the beginning of the rise of the water level, terrestrial biomarker contents increased in the profile due to lixiviation of the catchment before definitive soil flooding. These inputs indicated watershed erosion, certainly due to heavier rainfall, suggesting a more humid phase. At 5000 cal yr BP the level of the water column remained the same; the mineral input suspended represented the majority of the deposited material, thereby masking the OM signal. During the period between 5000 and 2700 cal yr BP, two units (UIII and UII) were clearly 
differentiated thanks to RE results. Biomarkers and organic petrography evidenced that, in spite of the increasing level of the water column, the OM sedimented in the Curuai Floodplain was poorly preserved. This was possibly due to river input of $\mathrm{OM}$ originating from the Amazon basin. From 3000 yr cal BP, PTMEs evidenced that the Poaceae genuses at this time were probably different from those found at the bottom and top of the profile (middleHolocene), suggesting different vegetation cover during a period of 2000 years. The last 600 cal yr BP were marked by the strong influence of the Amazon River, that during periods of high water is responsible for aquatic OM input into the Curuai Floodplain. During periods of low water, part of the OM highly degraded comes from the Amazon River and the other part comes from Curuai catchment land-derived. The same OM characteristics are observed today in surface sediments of the Curuai Floodplain.

Acknowledgments The study was accomplished as part of a collaborative project between the IRD-France, CNPq-Brasil and ISTO/CNRS. The Curuai Floodplain is being studied within the framework of the HYBAM network (Service National d'Observation INSU/CNRS). It was also supported by a CNRS/INSU/PALEO2 - PASCAL project (PASt climate change impacts on Carbon Accumulation in Amazonia floodplain Lakes). One of the authors (R.Z.) received financial support from the CNPq and CAPES. The authors also wish to thank Ryan Hladyniuk and two anonymous reviewers for the constructive comments.

\section{References}

Aalto, R., Maurice-Bourgoin, L., Dunne, T., Montgomery, D.R., Nittrouer, C.A., Guyot, J.L., 2003. Episodic sediment accumulation on Amazonian flood plains influenced by El Niño/Southern oscillation. Nature 425, 493-497.

Andersson, R.A. and Meyers, P.A., 2012. Effect of climate change on delivery and degradation of lipid biomarkers in a Holocene peat sequence in the Eastern European Russian Arctic. Organic Geochemistry 53, 63-72. 
Aufdenkampe, A.K., Mayorga, E., Raymond, P.A., Melack, J.M., Doney, S.C., Alin, S.R., Aalto, R.E., Yoo, K., 2011. Riverine coupling of biogeochemical cycles between land, oceans, and atmosphere. Frontiers in Ecology and the Environment 9, 53-60.

Bardy, M., Derenne, S., Fritsch, E., 2009. Evolution of lipid abundance and molecular composition during the podzolisation of laterites in the upper Amazon basin. Biogeochemistry 92, 95-118.

Baudin, F., Disnar, J-R., Aboussou, A., Savignac, F., Guidelines for Rock-Eval analysis of recent marine sediments. Organic Geochemistry 86, 71-80.

Bishop, A.N., Love, G.D., McAulay, A.D., Snape, C.E., Farrimond, P., 1998. Release of kerogenbound hopanoids by hydropyrolysis. Organic Geochemistry 29, 989-1001.

Bonnet, M.P., Barroux, G., Martinez, J.M., Seyler, F., Moreira-Turcq, P., Cochonneau, G., Melack, J.M., Boaventura, G., Maurice-Bourgoin, L., León, J.G., Roux, E., Calmant, S., Kosuth, P., Guyot, J.-L., Seyler, P., 2008. Floodplain hydrology in an Amazonian floodplain lake (Lago Grande de Curuai). Journal of Hydrology 349, 18-30.

Bray, E.E., Evans, E.D., 1961. Distribution of $n$-paraffins as a clue to recognition of source beds. Geochimica et Cosmochimica Acta 22, 2-15.

Bull, I.D., Van Bergen, P.F., Poulton, P.R., Evershed, R.P., 1998. Organic geochemical studies of soils from the Rothamsted Classical Experiments - II. Soils from the Hoosfield Spring Barley Experiment treated with different quantities of manure. Organic Geochemistry 28, 11-26.

Cardoso, A.G.A., 2004. Reconstrução paleoambiental na Lagoa do Caçó (Maranhão-Brasil) durante os ultimos 21.000 anos A.P. por marcadores e processos inorgânicos sedimentares. $\mathrm{PhD}$ dissertation, Department of Geochemistry, Universidade Federal Fluminense, 127 pp.

Corbet, B., 1980. Origine et transformation des triterpènes dans les sédiments récents. Ph.D. thesis, Université Louis Pasteur, Strasbourg, France, 106 pp.

Cranwell, P.A., 1984. Organic geochemistry of lacustrine sediments: triterpenoids of higher plant origin reflecting post-glacial vegetational succession. In: Haworth, E.Y., Lund, J.W.G. (Eds.), Lakes Sediments and Environmental History. University Press, Leicester, UK, pp. 69-92.

Cranwell, P.A., 1980. Branched/cyclic alkanols in lacustrine sediments (Great Britain): recognition of iso- and anteiso-branching and stereochemical analysis of homologous alkan-2-ols. Chemical Geology 30, 15-26.

Disnar, J.-R., Guillet, B., Kéravis, D., Di Giovanni, C., Sebag, D. 2003. Soil organic matter (SOM) characterisation by Rock-Eval pyrolysis: main possibilities and limitations. Organic Geochemistry, 34, 327-343.

Eglinton, G., Gonzalez, A.G., Hamilton, R.J., Raphael, R.A., 1962. Hydrocarbon constituents of the wax coatings of plant leaves: a taxonomic survey. Phytochemistry 1, 89-102.

Espitalié, J., Deroo, G., Marquis, F., 1986. La pyrolyse Rock-Eval et ses applications, troisième partie. Revue de l'Institut Français du Pétrole 41, 73-89.

Espitalié, J., Deroo, G., Marquis, F., 1985. La pyrolyse Rock-Eval et ses applications, première partie. Revue de l'Institut Français du Pétrole 40, 563-579. 
Farrimond, P., Love, G.D., Bishop, A.N., Innes, H., Watson, D.F., Snape, C.E., 2003. Evidence for the rapid incorporation of hopanes into kerogen. Geochimica et Cosmochimica Acta 67, 1383-1394.

Ficken, K.J., Li, B., Swain, D.L., Eglinton, G., 2000. An $n$-alkane proxy for the sedimentary input of submerged/floating freshwater aquatic macrophytes. Organic Geochemistry 31, 745-749.

Garel, S., Schnyder, J., Jacob, J., Dupuis, C., Boussafir, M., Le Milbeau, C., Storme, J.Y., Iakovleva, A.I., Yans, J., Baudin, F., Fléoch, C., Quesnel, F., 2013. Paleohydrological and paleoenvironmental changes recorded in terrestrial sediments of the Paleocene-Eocene boundary (Normandy, France). Palaeogeography, Palaeoclimatology, Palaeoecology 376, 184-199.

Gelpi, E., Schneider, H., Mann, J., Oró, J., 1970. Hydrocarbons of geochemical significance in microscopic algae. Phytochemistry 9, 603-612.

Hazai, I., Alexander, G., Szekely, T., Essinger, B., Radek, D., 1986. Investigations of hydrocarbons constituents of a young sub-bituminous coal by gas chromatography-mass spectrometry. Journal of Chromatography 367, 117-133.

Ho, E.S., Meyers, P.A., 1994. Variability of early diagenesis in lake sediments: Evidence from the sedimentary geolipid record in an isolated tarn. Chemical Geology 112, 309-324.

Huang, X., Xue, J., Wang, X., Meyers, P.A., 2015. Environmental controls on leaf wax $\delta$ D ratios in surface peats across the monsoonal region of China. Biogeosciences Discussions 12, 1515715184.

Huang, X., Xue, J., Wang, X., Meyers, P.A., Huang, J., Xie, S., 2013. Paleoclimate influence on early diagenesis of plant triterpenes in the Dajiuhu peatland, central China. Geochimica et Cosmochimica Acta 123, 106-119.

Innes, H.E., Bishop, A.N., Head, I.M., Farrimond, P., 1997. Preservation and diagenesis of hopanoids in Recent lacustrine sediments of Priest Pot, England. Organic Geochemistry 26, 565-576.

Jacob, J., Disnar, J.-R., Boussafir, M., Albuquerque, A.L.S., Sifeddine, A., Turcq, B., 2007. Contrasted distributions of triterpene derivatives in the sediments of Lake Caçó reflect paleoenvironmental changes during the last 20,000 yr in NE Brazil. Organic Geochemistry 38, 180-197.

Jacob, J., Disnar, J.-R., Boussafir, M., Sifeddine, A., Albuquerque, A.L.S., Turcq, B., 2005. Pentacyclic triterpene methyl ethers in recent lacustrine sediments (Lake Caço, Brazil). Organic Geochemistry 36, 449-461.

Jacob, J., Disnar, J.R., Boussafir, M., Sifeddine, A., Albuquerque, A.L.S., Turcq, B., 2004. Major environmental changes recorded by lacustrine sedimentary organic matter since the Last Glacial Maximum under the tropics (Lagoa do Caçó, NE Brazil).Palaeogeography, Palaeoclimatology, Palaeoecology 205, 183-197.

Jacob, J. (2003). Enregistrement des variations paléoenvironnementales depuis 20000 ans dans le Nord Est du Brésil (Lac Caço) par les triterpènes et autres marqueurs organiques. Ph.D. thesis, Université d'Orléans, France, 296 pp. 
Jaffé, R., Wolff, G.A., Cabrera, A.C., Carvajal-Chitty, H.I., 1995. The biogeochemistry of lipids in rivers of the Orinoco Basin. Geochimica et Cosmochimica Acta 59, 4507-4522.

Jansen, B., Nierop, K.G.J., 2009. Methyl ketones in high altitude Ecuadorian Andosols confirm excellent conservation of plant-specific n-alkane patterns. Organic Geochemistry 40, 61-69.

Katz, B.J., 1983. Limitations of 'Rock-Eval' pyrolysis for typing organic matter. Organic Geochemistry 4, 195-199.

Killops, S.D., Killops, V.J., 2004. An Introduction to Organic Geochemistry, second ed. Blackwell Publishing, Oxford, 408 pp.

Killops, S.D., Raine, J.I., Woolhouse, A.D., Weston, R.J., 1995. Chemostratigraphic evidence of higher-plant evolution in the Taranaki Basin, New-Zealand. Organic Geochemistry 23, 429-445.

Laflamme R.E., Hites, R.A., 1979. Tetra- and pentacyclic, naturally-occurring, aromatic hydrocarbons in recent sediments. Geochimica et Cosmochimica Acta 43, 1687-1691.

Lavrieux, M.L., Bréheret, J.G., Disnar, J.-R., Jacob, J., Le Milbeau, C., Zocatelli, R., 2012. Preservation of an ancient grassland biomarker signature in a forest soil from the French Massif Central. Organic Geochemistry 51, 1-10.

Lavrieux, M., Jacob, J., Le Milbeau, C., Zocatelli, R., Masuda, K., Bréheret, J.-G., Disnar, J.-R., 2011. Occurrence of triterpenyl acetates in soil and their potential as chemotaxonomical markers of Asteraceae. Organic Geochemistry 42, 1315-1323.

Le Milbeau, C., Lavrieux, M., Jacob, J., Bréheret, J.-G., Zocatelli, R., Disnar, J.-R., 2013. Methoxyserratenes in a soil under conifers and their potential use as biomarkers of Pinaceae. Organic Geochemistry 55, 45-54.

LSBF, 2010. List of Species of the Brazilian Flora. Rio de Janeiro Botanical Garden. <http://floradobrasil.jbrj.gov.br/>. Access on: 19 Nov. 2014.

Logan, G.A., Eglinton, G., 1994. Biogeochemistry of the Miocene lacustrine deposit, at Clarkia, northern Idaho, USA. Organic Geochemistry 21, 857-870.

Love, G.D., Snape, C.E., Carr, AD., Houghton, R.C., 1995. Release of covalently-bound alkane biomarkers in high yields from kerogen via catalytic hydropyrolysis. Organic Geochemistry 23, 981-986.

Marchand, C., Lallier-Vergès, E., Disnar, J.-R., Kéravis, D., 2008. Organic carbon sources and transformations in mangrove sediments: A Rock-Eval pyrolysis approach. Organic Geochemistry $39,408-421$.

Maurice-Bourgoin, L., Bonnet, M.-P., Martinez, J.-M., Kosuth, P., Cochonneau, G., Moreira-Turcq, P., Guyot, J.-L., Vauchel, P., Filizola, N., Seyler, P., 2007. Temporal dynamics of water and sediment exchanges between the Curuai floodplain and the Amazon River, Brazil. Journal of Hydrology 335, 140-156.

Melfi, A.J., Fritsch, E., Boulet, R., Seyler, F., Carvalho, A., Magat, P. 1996. Distribuição dos solos nas paisagens lateríticas da Amazônia: elaboração de um modelo conceitual ilustrando a evolução 
hidro-biogeoquímica destas paisagens. In: XIII Congresso Latino Americano de Ciência do Solo, Solo-Suelo, 1996, Águas de Lindóia. Anais do Congresso.

Meyers, P.A., Ishiwatari, R., 1993. Lacustrine organic geochemistry - an overview of indicators of organic matter sources and diagenesis in lake sediments. Organic Geochemistry 20, 867-900.

Moreira-Turcq P., Bonnet M.-P., Amorim M., Bernardes M., Lagane C., Maurice L., Perez M., Seyler P., 2013. Seasonal variability in concentration, composition, age, and fluxes of particulate organic carbon exchanged between the floodplain and Amazon River. Global Biogeochemistry Cycles 27, $119-130$.

Moreira-Turcq, P., Barroux, M., Bernardes, M., Bonet, M.-P., Maurice-Bourgoin, L., Perez, M., Seyler, P., 2005. Dynamics of organic carbon between the Amazon River and flood plain lakes. In: Dynamics and Biogeochemistry of River Corridors and Wetlands. IAHS Publication. Netherlands, 19-23.

Moreira-Turcq, P., Jouanneau, J.-M., Turcq, B., Seyler, P., Weber, O., Guyot, J.-L., 2004. Carbon sedimentation at Lago Grande de Curuai, a floodplain Lake in the low Amazon Region: insights into sedimentation rates. Palaeogeography, Palaeoclimatology, Palaeoecology 214, 27-40.

Moreira, L. S., Moreira-Turcq, P., Turcq, B., Caquineau, S., Cordeiro, R.C., 2012. Paleohydrological changes in an Amazonian floodplain lake: Santa Ninha. Journal of Paleolimnology 48, 339-350.

Mortillaro, J.M., Abril, G., Moreira-Turcq, P., Sobrinho, R.L., Perez, M., Meziane, T., 2011. Fatty acid and stable isotope $\left(\delta^{13} \mathrm{C}, \delta^{15} \mathrm{~N}\right)$ signatures of particulate organic matter in the lower Amazon River: Seasonal contrasts and connectivity between floodplain lakes and the mainstem. Organic Geochemistry 42, 1159-1168.

Nakamura, H., Sawada, K., Takahashi, M., 2010. Aliphatic and aromatic terpenoid biomarkers in Cretaceous and Paleogene angiosperm fossils from Japan. Organic Geochemistry 41, 975-980.

Peters, K., Walters, C., Moldowan, M., 2005. The biomarker guide, Cambridge university press. ed. New York. 704 pp.

RADAMBRASIL. Projeto RADAMBRASIL, 1976. Levantamento de Recursos Naturais, 10 (Folha SA 21, Santarém). Departamento Nacional da Produção Mineral, Rio de Janeiro, 522 pp.

Richey, J.R., Hedges, J.I., Devol, A.H., Quay, P.D., Victoria, R., Martinelli, L.A., Forsberg, B.R., 1990. Biogeochemistry of carbon in the Amazon River. Limnology and Oceanography 35, 352371.

Rieley, G., Collier, R.J., Jones, D.M., Eglinton, G., 1991. The biogeochemistry of Ellesmere Lake, UK - I: source correlation of leaf wax inputs to the sedimentary lipid record. Organic Geochemistry $17,901-912$.

Roddaz, M., Viers, J., Moreira-Turcq, P., Blondel, C., Sondag, F., J-L. Guyot, Moreira, L., 2014. Evidence for the control of the geochemistry of Amazonian floodplain sediments by stratification of suspended sediments in the Amazon. Chemical Geology 387, 101-110.

Rohmer, M., Bouvier-Nave, P., Ourisson, G., 1984. Distribution of hopanoid triterpenes in prokaryotes. Journal of General Microbiology 130, 1137-1150. 
Sebag, D., Disnar, J.-R., Guillet, B., Di Giovanni, C., Verrecchia, E.P., Durand, A., 2006. Monitoring organic matter dynamics in soil profiles by 'Rock-Eval pyrolysis': Bulk characterization and quantification of degradation. European Journal of Soil Science 57, 344-355.

Seyler, P., Boaventura, G.R., 2003. Distribution and partition of trace metals in the Amazon Basin. Hydrol Process 17, 1345-1361.

Simoneit, B.R.T., 2004. A review of current applications of mass spectrometry for biomarker/molecular tracer elucidations. Mass Spectrometry Reviews 24, 719-765.

Simonneau, A., Chapron, E., Vannière, B., Wirth, S.B., Gilli, A., Di Giovanni, C., Anselmetti, F.S., Desmet, M., Magny, M. 2013. Mass-movement and flood-induced deposits in Lake Ledro, southern Alps, Italy: implications for Holocene palaeohydrology and natural hazards. Climate of the Past 9, 825-840.

Sobrinho, R. L., Bernardes, M.C., Abril, G., Kim, J.-H., Zell, C.I., Mortillaro, J.-M., Meziane, T., Moreira-Turcq, P., Sinninghe Damsté, J. S., 2015. Spatial and seasonal contrasts of sedimentary organic matter in floodplain lakes of the central Amazon basin. Biogeosciences Discuss., 12, 8747-8787.

Stefanova, M., Magnier, C., Velinova, D., 1995. Biomarker assemblage of some Miocene-aged Bulgarian lignite lithotypes. Organic Geochemistry 23, 1067-1084.

Stout, S., 1992. Aliphatic and aromatic triterpenoid hydrocarbons in Tertiary angiospermous lignite. Organic Geochemistry 18, 51-66.

Tan, Y.L., Heit, M., 1981. Biogenic and abiogenic polynuclear aromatic hydrocarbons in sediments from two remote Adirondack lakes. Geochimica et Cosmochimica Acta 45, 2267-2279.

Tissot, B.P., Welte, D.H., 1984. Petroleum Formation and Occurrence. Berlin: Springer-Verlag.

Trendel J. M., Lohmann F., Kintzinger J. P., Albrecht P., Chiarone A., Riche C., Cesario M., Guilhem J. and Pascard C., 1989. Identification of des-A-triterpenoid hydrocarbons occurring in surface sediments. Tetrahedron 45, 4457-4470.

Trendel, J., 1985. Dégradation des triterpènes dans les sédiments. Aspects photochimiques et microbiologiques. Ph.D. thesis, Université Louis Pasteur, Strasbourg, France, 126 pp.

Turcq, B., Albuquerque, A.L.S., Cordeiro, R.C., Sifeddine, A., Simões Filho, F.L.A., Souza, G., Abrão, J.J., Oliveira, F.B.L., Silva, A.O., Capitâneo, J.A., 2002. Accumulation of organic carbon in five Brazilian lakes during the Holocene. Sedimentary Geology 148, 319-342.

Tyson, R.V., 1995. Sedimentary Organic Matter: Organic Facies and Palynofacies Analysis. Chapman \& Hall, London, 615 pp.

van Bergen, P., Bull, I., Poulton, P.R., Evershed, R.P., 1997. Organic geochemical studies of soils from the Rothamsted Classical Experiments - 1. Total lipid extracts, solvent insoluble residues and humic acids from Broadbalk Wilderness. Organic Geochemistry 26, 117-135.

van Dongen, B.E., Talbot, H.M., Schouten, S., Pearson, P.N., Pancost, R.D., 2006. Well preserved Palaeogene and Cretaceous biomarkers from the Kilwa area, Tanzania. Organic Geochemistry 37, 539-557. 
Wakeham, S.G., Schaffner, C., Giger, W., 1980. Polycyclic aromatic hydrocarbons in recent lake sediments - II. Compounds derived from biogenic precursors during early diagenesis. Geochimica et Cosmochimica Acta 44, 415-429.

Wolff, G.A., Trendel, J.M., Albrecht, P., 1989. Novel monoaromatic triterpenoids hydrocarbons occurring in sediments. Tetrahedron 45, 6721-6728.

Xie, S., Nott, C., Avsejs, L., Maddy, D., Chambers, F., Evershed, R., 2004. Molecular and isotopic stratigraphy in an ombrotrophic mire for paleoclimate reconstruction. Geochimica et Cosmochimica Acta 68, 2849-2862.

Zheng, Y., Zhou, W., Meyers, P.A., Xie, S., 2007. Lipid biomarkers in the Zoigê-Hongyuan peat deposit: indicators of Holocene climate changes in West China. Organic Geochemistry 38, $1927-$ 1940.

Zhou, W., Zheng, Y., Meyers, P.A., Jull, A.J.T., Xie, S., 2010. Postglacial climate-change record in biomarker lipid compositions of the Hani peat sequence, Northeastern China. Earth and Planetary Science Letters 294, 37-46.

Zocatelli, R., Jacob, J., Gogo, S., Le Milbeau, C., Rousseau, J., Laggoun-Défarge, F., 2014. Spatial variability of soil lipids reflects vegetation cover in a French peatland. Organic Geochemistry 76 173-183.

Zocatelli, R., Moreira-Turcq, P., Bernardes, M., Turcq, B., Cordeiro, R.C., Gogo, S., Disnar, J.-R., Boussafir, M., 2013. Sedimentary evidence of soil organic matter input to the Curuai Amazonian floodplain. Organic Geochemistry 63, 40-47.

Zocatelli, R., Lavrieux, M., Disnar, J.-R., Le Milbeau, C., Jacob, J., Bréheret, J.-G., 2012a. Free fatty acids in Lake Aydat catchment soils (French Massif Central): sources, distributions and potential use as sediment biomarkers. Journal of Soils Sediments 12, 734-748.

Zocatelli, R., Turcq, B., Boussafir, M., Cordeiro, R.C., Disnar, J.-R., Costa, R.L., Sifeddine, A., Albuquerque, A.L.S., Bernardes, M.C., Jacob, J., 2012b. Late Holocene paleoenvironmental changes in Northeast Brazil recorded by organic matter in lacustrine sediments of Lake Boqueirão. Palaeogeography, Palaeoclimatology, Palaeoecology 363-364, 127-134.

Zocatelli, R., Cecanho, F., Amorim, M., Bernardes, M., Moreira-Turcq, P., Turcq, B., Sifeddine, A., Cordeiro, R.C, 2011. Uso dos fenóis da lignina no estudo da matéria orgânica na Várzea do Lago Grande Curuai, Pará e no Lago do Caçó, Maranhão, Brasil. Acta Amazonica 41, 195-204.

Zocatelli, R., Jacob, J., Turcq, B., Boussafir, M., Sifeddine, A., Bernardes, M.C., 2010. Molecular evidence for recent turf cultivation in Northeast Brazil (Lagoa do Boqueirão, RN State). Organic Geochemistry 41, 427-430. 


\section{TABLE CAPTIONS}

Table 1: Table 1: List of compounds identified in TA14 sediments samples. Identifications were made from standard compounds when available and comparison with the following references: L: Logan and Eglinton (1994); C: Corbet (1980); H: Huang et al. (2013); T: Trendel et al. (1989); L1: Laflamme and Hites (1979); H1: Hazai et al. (1986); W: Wolff et al. (1989); S: Stout (1992); S1: Shiojima et al. (1992); J1: Jacob et al. (2007); K: Killops et al. (1995), W1: Wakeham et al. (1980); J2: Jacob, (2003); J3: Jacob et al. (2005).

Table 2: Distributions, abundances and ratios of $n$-alkanes in TA14 samples.

\section{Legend:}

${ }^{a}$ Distribution of $n$-alkanes in core samples;

${ }^{\mathrm{b}}$ Majors $n$-alkanes homologues in core samples;

${ }^{\mathrm{c}}$ Total $=$ total abundance $(\mu \mathrm{g} / \mathrm{g}$ of soils $)$;

${ }_{\mathrm{d}}$ odd/even ratio, odd/even $=\sum$ conc. odd $n$-alkanes $/ \sum$ conc. even $n$-alkanes

${ }^{\mathrm{e}} n$-Alkane carbon preference index; CPI $=2\left(\right.$ odd $n-\mathrm{C}_{23}$ to $\left.n-\mathrm{C}_{31}\right) /\left(\right.$ even $n-\mathrm{C}_{22}$ to $n-\mathrm{C}_{30}+$ even $n-\mathrm{C}_{24}$ to $\left.n-\mathrm{C}_{32}\right)$.

${ }^{\mathrm{f}} \mathrm{Paq}$ ratio; $\mathrm{Paq}=\left(n-\mathrm{C}_{23}+n-\mathrm{C}_{25}\right) /\left(n-\mathrm{C}_{23}+n-\mathrm{C}_{25}+n-\mathrm{C}_{29}+n-\mathrm{C}_{31}\right)$

Table 3: Abundance of pentacyclic triterpene derivatives (des-A-triterpenes and aromatics), hopanes and PTMEs in TA14 samples.

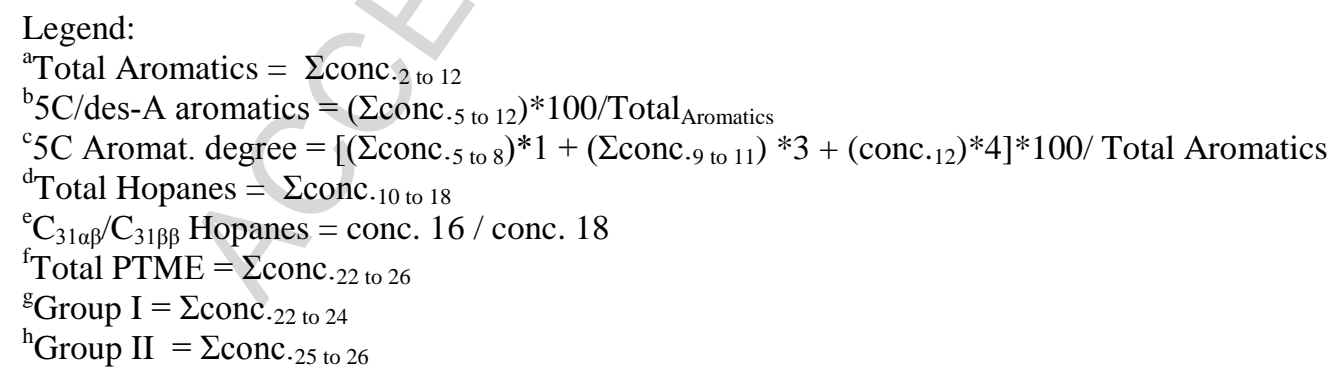

\section{FIGURE CAPTIONS}

Fig. 1 - Localization of the Curuai Floodplain and TA14 core. Numbers represent interconnected lakes: 1- Lake Santa Ninha, 2- Lake Poção and 3- Lake Grande.

Fig. 2 - TA14 picture, datation (cal yr BP), lithology, and units description, after Moreira et al. (2012) (a); Sample selection for bulk analysis (black squares), HI and OI profiles and 
sample selection for organic petrology and molecular analysis (black arrows) (b) and The S2 curve (c).

Fig. 3 - Pseudo van-Krevelen type diagram for TA14 profile (a) and HI versus Tmax. Diagrams adapted by Baudin et al. (2015) and Espitalié et al. (1986).

Fig. 4 - Relative distribution of organic particles identified by organic petrography and representative pictures. $\mathrm{rAOM}=$ reddish amorphous organic matter, $\mathrm{FAOM}=$ flocculated amorphous organic matter, $\mathrm{LC}=$ lignocellulosic particles and $\mathrm{Mb}=$ membrane particles.

Fig. 5 - Fractions extracted from lacustrine sediments of TA14 core (sample 196 centimetres). Specific ion mass chromatograms of $n$-alkanes (a); derivative pentacyclic triterpenes and hopanes (b); and pentacyclic triterpene methyl ethers (PTMEs) in fraction 3 (c). The nomenclature of compounds refers to Table 1.

Fig. 6 - Synthetic presentation of biomarkers and biomarkers ratio evolution along core TA14 retrieved in Curuai Floodplain:

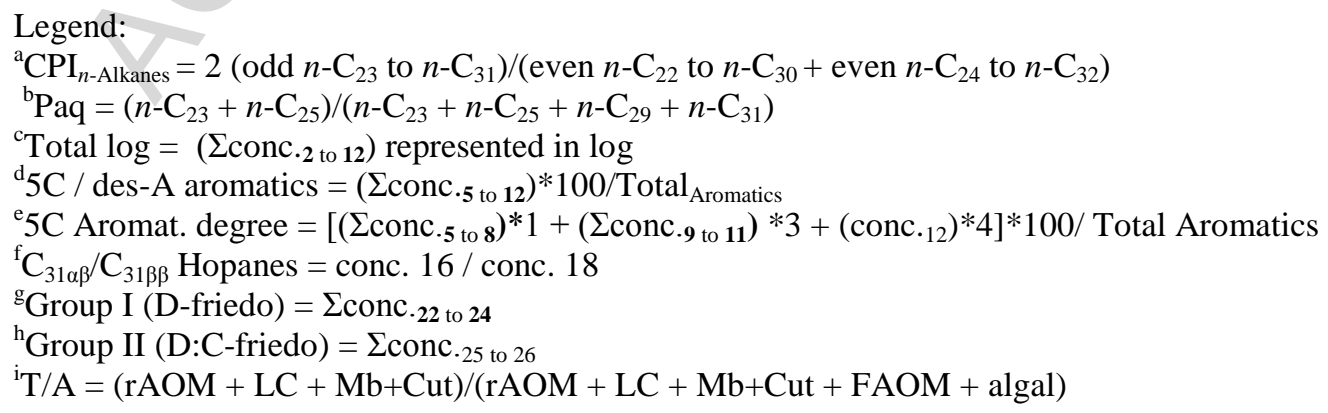


Table 1: List of compounds identified in TA14 sediments samples. Identifications were made from standard compounds when available and comparison with the following references: L: Logan and Eglinton (1994); C: Corbet (1980); H: Huang et al. (2013); T: Trendel et al. (1989); L1: Laflamme and Hites (1979); H1: Hazai et al. (1986); W: Wolff et al. (1989); S: Stout (1992); S1: Shiojima et al. (1992); J1: Jacob et al. (2007); K: Killops et al. (1995), W1: Wakeham et al. (1980); J2: Jacob, (2003); J3: Jacob et al. (2005).

\begin{tabular}{|c|c|c|c|c|c|}
\hline $\begin{array}{l}\text { Peak } \\
\text { no. }\end{array}$ & Formula & $\begin{array}{l}\text { Molecular } \\
\text { mass }\end{array}$ & Most significant ions & Indentification & References \\
\hline \multicolumn{6}{|c|}{$n$-Alkanes } \\
\hline I & $\mathrm{C}_{\mathrm{n}} \mathrm{H}_{2 \mathrm{n}+2}$ & $254-464$ & $57,71,85$ & $n-\mathrm{C}_{18}$ to $n-\mathrm{C}_{33}$ & $\mathrm{~L}$ \\
\hline \multicolumn{6}{|c|}{ Pentacyclic triterpene derivatives } \\
\hline \multicolumn{6}{|c|}{ des-A-triterpene } \\
\hline 1 & $\mathrm{C}_{24} \mathrm{H}_{42}$ & 330 & $\begin{array}{l}163,149,191,177,206 \\
287,217,315,330\end{array}$ & des-A-lupane & $\mathrm{C}, \mathrm{J} 1(5)$ \\
\hline \multicolumn{6}{|c|}{ Aromatics } \\
\hline 2 & $\mathrm{C}_{22} \mathrm{H}_{28}$ & 292 & $\begin{array}{l}292,207,277,168,181 \\
193\end{array}$ & des-A-dinoroleana-5,7,9,11,13-pentaene & $\mathrm{H}(1), \mathrm{T}(3)$ \\
\hline 3 & $\mathrm{C}_{22} \mathrm{H}_{28}$ & 292 & $207,292,193$ & des-A-dinorursa-5,7,9,11,13-pentaene & $\mathrm{H}(2), \mathrm{T}(14)$ \\
\hline 4 & $\mathrm{C}_{22} \mathrm{H}_{28}$ & 292 & $207,292,193,249$ & des-A-dinorlupa-5,7,9,11,13-pentaene & $\mathrm{H}(3), \mathrm{L} 1(4)$ \\
\hline 5 & $\mathrm{C}_{28} \mathrm{H}_{40}$ & 376 & $\begin{array}{l}145,172,156,189,204 \\
361,376\end{array}$ & dinor-oleana(ursa)-1,3,5(10),12-tetrane & $\begin{array}{l}\mathrm{H} 1(38,34,35,31) \\
\mathrm{W}(7 \mathrm{c}), \mathrm{J} 1(11)\end{array}$ \\
\hline 6 & $\mathrm{C}_{28} \mathrm{H}_{42}$ & 376 & $\begin{array}{l}170,155,145,209,285 \\
225,361,376\end{array}$ & dinor-oleana(ursa)-1,3,5(10),13(18)-tetrane & $\mathrm{S}(29), \mathrm{J} 1(12)$ \\
\hline 7 & $\mathrm{C}_{28} \mathrm{H}_{42}$ & 378 & $145,157,172,378$ & dinor-oleana(ursa)-1,3,5(10)triene & $\begin{array}{l}\mathrm{H} 1(43), \mathrm{S}(32) \\
\mathrm{J} 1(15)\end{array}$ \\
\hline 8 & $\mathrm{C}_{28} \mathrm{H}_{42}$ & 378 & $145,157,172$ & dinor-lupa-1,3,5 (10)-triene & $\mathrm{W}(7 \mathrm{a}), \mathrm{J} 1(22)$ \\
\hline 9 & $\mathrm{C}_{26} \mathrm{H}_{30}$ & 342 & $342,218,231,257,327$ & $\begin{array}{l}\text { 24,25,26,27-tetranoroleana- } 1,3,5(10), \\
6,8,11,13 \text {-heptaene }\end{array}$ & $\begin{array}{l}\text { W1(19), L, } \\
\mathrm{H}(39), \mathrm{S}(39)\end{array}$ \\
\hline 10 & $\mathrm{C}_{26} \mathrm{H}_{30}$ & 342 & $\begin{array}{l}342,218,231,243,257 \\
327,271,285\end{array}$ & $\begin{array}{l}\text { 24,25,26,27-tetranorursa-1,3,5(10), } \\
6,8,11,13 \text {-heptaene }\end{array}$ & $\begin{array}{l}\mathrm{J} 1(20), \mathrm{H} 1(40) \\
\mathrm{S}(23)\end{array}$ \\
\hline 11 & $\mathrm{C}_{26} \mathrm{H}_{30}$ & 374 & $195,207,374,359,221$ & $\begin{array}{l}\text { 24,25,26,27-tetranorlupa-1,3,5(10), } \\
\text { 6,8,11,13-heptaene }\end{array}$ & $\begin{array}{l}\text { J1 (21), H1(47), } \\
\text { S (24) }\end{array}$ \\
\hline 12 & $\mathrm{C}_{25} \mathrm{H}_{26}$ & & $268,324,252$ & $\begin{array}{l}\text { 24,25,26,27,28-pentanoroleana- } 1,3,5(10) \\
6,8,11,13,15,17 \text {-heptaene }\end{array}$ & $\mathrm{K}$ \\
\hline \multicolumn{6}{|c|}{ Hopanes } \\
\hline 13 & $\mathrm{C}_{27} \mathrm{H}_{46}$ & 370 & $\begin{array}{l}149,191,95,370,69 \\
109\end{array}$ & $17 \alpha$ trisnorhopane & S1 \\
\hline 14 & $\mathrm{C}_{27} \mathrm{H}_{46}$ & 370 & $149,191,95,81,69,109$ & $17 \beta$ trisnorhopane & $\mathrm{S}(\mathrm{M})$ \\
\hline 15 & $\mathrm{C}_{29} \mathrm{H}_{50}$ & 398 & $\begin{array}{l}177,191,225,281,299 \\
359,383,384,398\end{array}$ & $17 \alpha, 21 \beta$ norhopane & $\mathrm{J} 2$ \\
\hline 16 & $\mathrm{C}_{29} \mathrm{H}_{50}$ & 398 & $\begin{array}{l}177,191,225,281,299 \\
359,383,384,398\end{array}$ & $17 \beta, 21 \alpha$ norhopane & $\mathrm{J} 2$ \\
\hline 17 & $\mathrm{C}_{30} \mathrm{H}_{52}$ & 412 & $205,191,95$ & $17 \alpha, 21 \beta$ hopane & $\mathrm{J} 2$ \\
\hline 18 & $\mathrm{C}_{29} \mathrm{H}_{50}$ & 398 & $177,191,95,81,69$ & $17 \beta, 21 \beta$ norhopane & $\mathrm{S}(\mathrm{Z})$ \\
\hline 19 & $\mathrm{C}_{31} \mathrm{H}_{54}$ & 426 & $191,95,205,81$ & $17 \alpha, 21 \beta$ homohopane & $\mathrm{S}\left(\mathrm{B}^{\prime}\right)$ \\
\hline 20 & $\mathrm{C}_{30} \mathrm{H}_{52}$ & 412 & 191,97 & $17 \beta, 21 \beta$ hopane & $\mathrm{S}\left(\mathrm{C}^{\prime}\right)$ \\
\hline 21 & $\mathrm{C}_{31} \mathrm{H}_{54}$ & 426 & $205,191,95$ & $17 \beta, 21 \beta$ homohopane & $S\left(D^{\prime}\right)$ \\
\hline \multicolumn{6}{|c|}{ PTMEs } \\
\hline 22 & $\mathrm{C}_{31} \mathrm{H}_{52} \mathrm{O}$ & 440 & $\begin{array}{l}204,189,218,425,408 \\
393,301,175,159\end{array}$ & $\begin{array}{l}\text { Taraxer-14-en-3 } \beta \text {-ol methyl ether } \\
\text { (crusgalin) }\end{array}$ & $\mathrm{J} 3(4)$ \\
\hline 23 & $\mathrm{C}_{31} \mathrm{H}_{52} \mathrm{O}$ & 440 & $\begin{array}{l}218,203,189,425,408 \\
393,355,255,243,229 \\
175,161\end{array}$ & $\begin{array}{l}\text { Urs-12-en-3 } \beta \text {-ol methyl ether ( } \alpha \text {-amyrin } \\
\text { ME) }\end{array}$ & $\mathrm{J} 3(5)$ \\
\hline 24 & $\mathrm{C}_{31} \mathrm{H}_{52} \mathrm{O}$ & 440 & $\begin{array}{l}218,204,189,425,408 \\
393,323,257,243 \\
229,177,161\end{array}$ & $\begin{array}{l}\text { Olean-12-en-3 } \beta \text {-ol methyl ether ( } \beta \text {-amyrin } \\
\text { ME, sawamilletin) }\end{array}$ & $\mathrm{J} 3(6)$ \\
\hline
\end{tabular}



$229,215,201,189,365$ $355,323,287,26$

$26 \quad \mathrm{C}_{31} \mathrm{H}_{52} \mathrm{O} \quad 440$

273, 241, 425, 408, 393, Arbor-9(11)-en-3 $\beta$-ol methyl ether

$\mathrm{J} 3(15)$ 229, 215, 201, 189, 365, (cylindrin) 
Table 2: Distributions, abundances and ratios of $n$-alkanes in TA14 samples.

\begin{tabular}{|c|c|c|c|c|c|c|c|c|}
\hline \multirow[b]{2}{*}{ Unit } & \multirow[b]{2}{*}{ Depth. $(\mathrm{cm})$} & \multirow[b]{2}{*}{ Age (cal yr BP) } & \multicolumn{3}{|c|}{$n$-Alkanes } & \multirow[b]{2}{*}{ odd/even ${ }^{\mathrm{d}}$} & \multirow[b]{2}{*}{$\mathrm{CPI}^{\mathrm{e}}$} & \multirow[b]{2}{*}{$\mathrm{Paq}^{\mathrm{f}}$} \\
\hline & & & Distribution $^{\mathrm{a}}$ & Majors $^{\mathrm{b}}$ & Total $^{\mathrm{c}}(\mu \mathrm{g} / \mathrm{g} \mathrm{sed})$ & & & \\
\hline \multirow[t]{2}{*}{ UI } & 10 & 182.37 & $n-\mathrm{C}_{18-33}$ & $n-\mathrm{C}_{29}, n-\mathrm{C}_{27}, n-\mathrm{C}_{33}$ & 2.47 & 1.91 & 1.87 & 0.33 \\
\hline & 26 & 541.01 & $n-\mathrm{C}_{18-33}$ & $n-\mathrm{C}_{31}, n-\mathrm{C}_{29}, n-\mathrm{C}_{33}$ & 2.54 & 2.01 & 2.39 & 0.33 \\
\hline \multirow[t]{3}{*}{ UII } & 50 & 2713.14 & $n-\mathrm{C}_{18-33}$ & $n-\mathrm{C}_{29}, n-\mathrm{C}_{27}$ & 2.77 & 1.20 & 1.27 & 0.41 \\
\hline & 72 & 3216.89 & $n-\mathrm{C}_{18-33}$ & $\mathrm{n}-\mathrm{C}_{25}-n-\mathrm{C}_{31}$ & 3.00 & 0.92 & 1.42 & 0.47 \\
\hline & 96 & 3600.31 & $n-\mathrm{C}_{21-33}$ & $n-\mathrm{C}_{28}, n-\mathrm{C}_{29}, n-\mathrm{C}_{30}$ & 6.39 & 1.24 & 1.22 & 0.42 \\
\hline \multirow[t]{4}{*}{ UIII } & 124 & 4007.13 & $n-\mathrm{C}_{18-33}$ & $n-\mathrm{C}_{29}, n-\mathrm{C}_{27}, n-\mathrm{C}_{33}$ & 0.89 & 1.29 & 1.18 & 0.34 \\
\hline & 132 & 4135.38 & $n-\mathrm{C}_{18-33}$ & $n-\mathrm{C}_{29}, n-\mathrm{C}_{27}, n-\mathrm{C}_{33}$ & 0.80 & 1.24 & 1.21 & 0.3 \\
\hline & 140 & 4275.03 & $n-\mathrm{C}_{18-33}$ & $n-\mathrm{C}_{29}, n-\mathrm{C}_{22}$ & 1.86 & 0.96 & 1.07 & 0.28 \\
\hline & 150 & 4551.58 & $n-\mathrm{C}_{18-33}$ & $n-\mathrm{C}_{25}, n-\mathrm{C}_{29}, n-\mathrm{C}_{27}$ & 1.88 & 1.38 & 1.56 & 0.62 \\
\hline \multirow[t]{3}{*}{ UIV } & 168 & 5017.81 & $n-\mathrm{C}_{18-33}$ & $n-\mathrm{C}_{29}, n-\mathrm{C}_{27}, n-\mathrm{C}_{31}$ & 1.94 & 4.34 & 4.82 & 0.15 \\
\hline & 182 & 5061.1 & $n-\mathrm{C}_{18-33}$ & $n-\mathrm{C}_{29}, n-\mathrm{C}_{27}, n-\mathrm{C}_{31}$ & 3.53 & 4.48 & 4.59 & 0.17 \\
\hline & 196 & 5109.3 & $n-\mathrm{C}_{18-33}$ & $n-\mathrm{C}_{29}$ & 8.30 & 3.10 & 3.68 & 0.18 \\
\hline \multirow[t]{2}{*}{ UV } & 212 & 5159.7 & $n-\mathrm{C}_{18-33}$ & $n-\mathrm{C}_{29}$ & 3.68 & 2.53 & 3.26 & 0.27 \\
\hline & 240 & 5222.03 & $n-\mathrm{C}_{18-33}$ & $n-\mathrm{C}_{25}, n-\mathrm{C}_{27}, n-\mathrm{C}_{29}$ & 3.68 & 3.25 & 4.07 & 0.38 \\
\hline
\end{tabular}

Legend:

${ }^{a}$ Distribution of $n$-alkanes in core samples;

${ }^{\mathrm{b}}$ Majors $n$-alkanes homologues in core samples;

${ }^{\mathrm{c}}$ Total $=$ total abundance $(\mu \mathrm{g} / \mathrm{g}$ of soils $)$;

${ }^{\mathrm{d}}$ odd/even ratio, odd/even $=\sum$ conc. odd $n$-alkanes $/ \sum$ conc. even $n$-alkanes

${ }^{\mathrm{e}} n$-Alkane carbon preference index; $\mathrm{CPI}=2\left(\right.$ odd $n-\mathrm{C}_{23}$ to $\left.n-\mathrm{C}_{31}\right) /\left(\right.$ even $n-\mathrm{C}_{22}$ to $n-\mathrm{C}_{30}+$ even $n-\mathrm{C}_{24}$ to $n$ - $\left.\mathrm{C}_{32}\right)$.

${ }^{\mathrm{f}} \mathrm{Paq}$ ratio; $\mathrm{Paq}=\left(n-\mathrm{C}_{23}+n-\mathrm{C}_{25}\right) /\left(n-\mathrm{C}_{23}+n-\mathrm{C}_{25}+n-\mathrm{C}_{29}+n-\mathrm{C}_{31}\right)$ 
Table 3: Abundance of pentacyclic triterpene derivatives (des-A-triterpenes and aromatics), hopanes and PTMEs in TA14 samples.

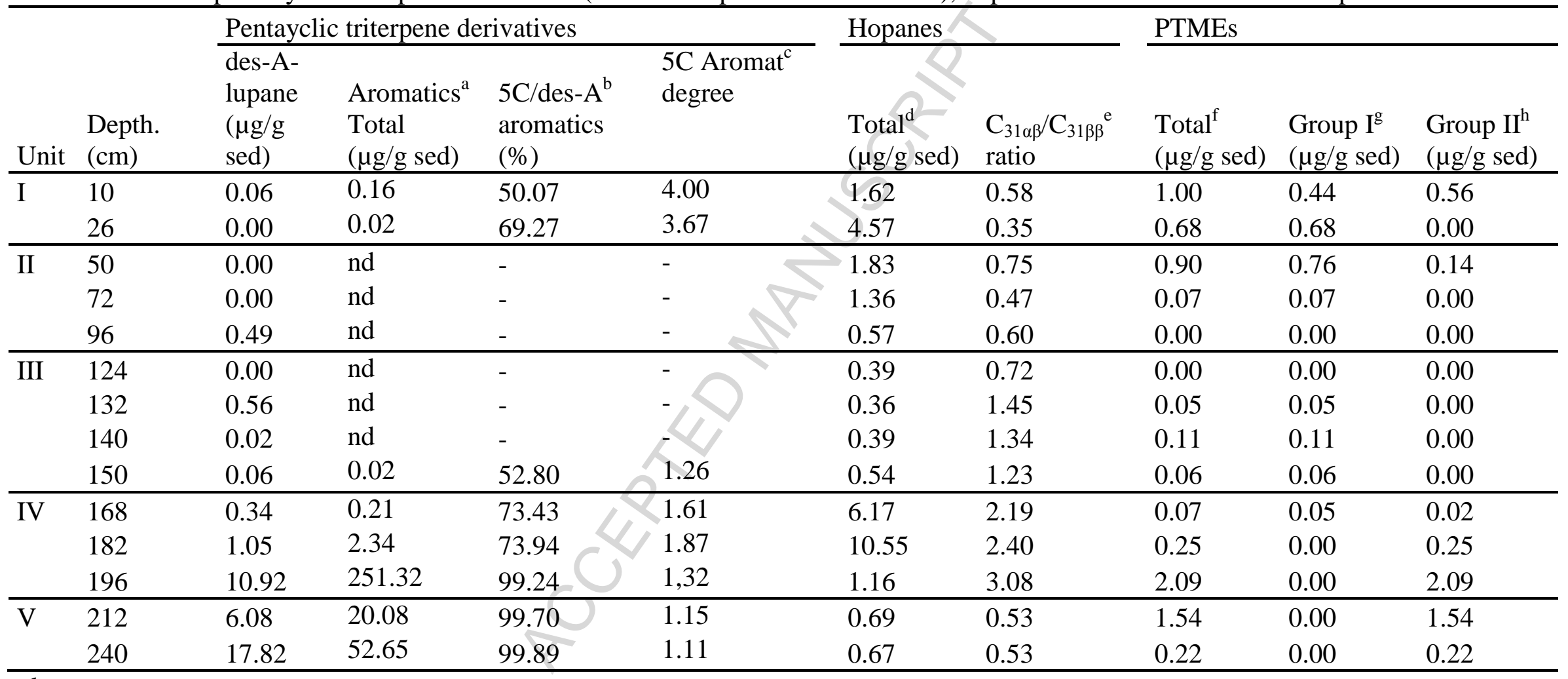

Legend:

${ }^{\mathrm{a}}$ Total Aromatics $=\Sigma$ conc. $_{2}$ to 12

${ }^{\mathrm{b}} 5 \mathrm{C} /$ des-A aromatics $=(\Sigma$ conc. 5 to 12$) * 100 /$ Total $_{\text {Aromatics }}$

${ }^{\mathrm{c}} 5 \mathrm{C}$ Aromat. degree $=\left[\left(\Sigma\right.\right.$ conc. $_{5}$ to 8$) * 1+(\Sigma$ conc. 9 to 11$) * 3+\left(\right.$ conc. $\left.\left._{12}\right) * 4\right] * 100 /$ Total Aromatics

${ }^{\mathrm{d}}$ Total Hopanes $=\Sigma$ conc. 10 to 18

${ }^{\mathrm{e}} \mathrm{C}_{31 \alpha \beta} / \mathrm{C}_{31 \beta \beta}$ Hopanes $=$ conc. $16 /$ conc 18

fotal PTME $=\Sigma$ conc. 22 to 26

${ }^{\mathrm{g}}$ Group I $=\Sigma$ conc.22 to 24

${ }^{\mathrm{h}}$ Group II $=\Sigma$ conc. 25 to 26 
Figure 1

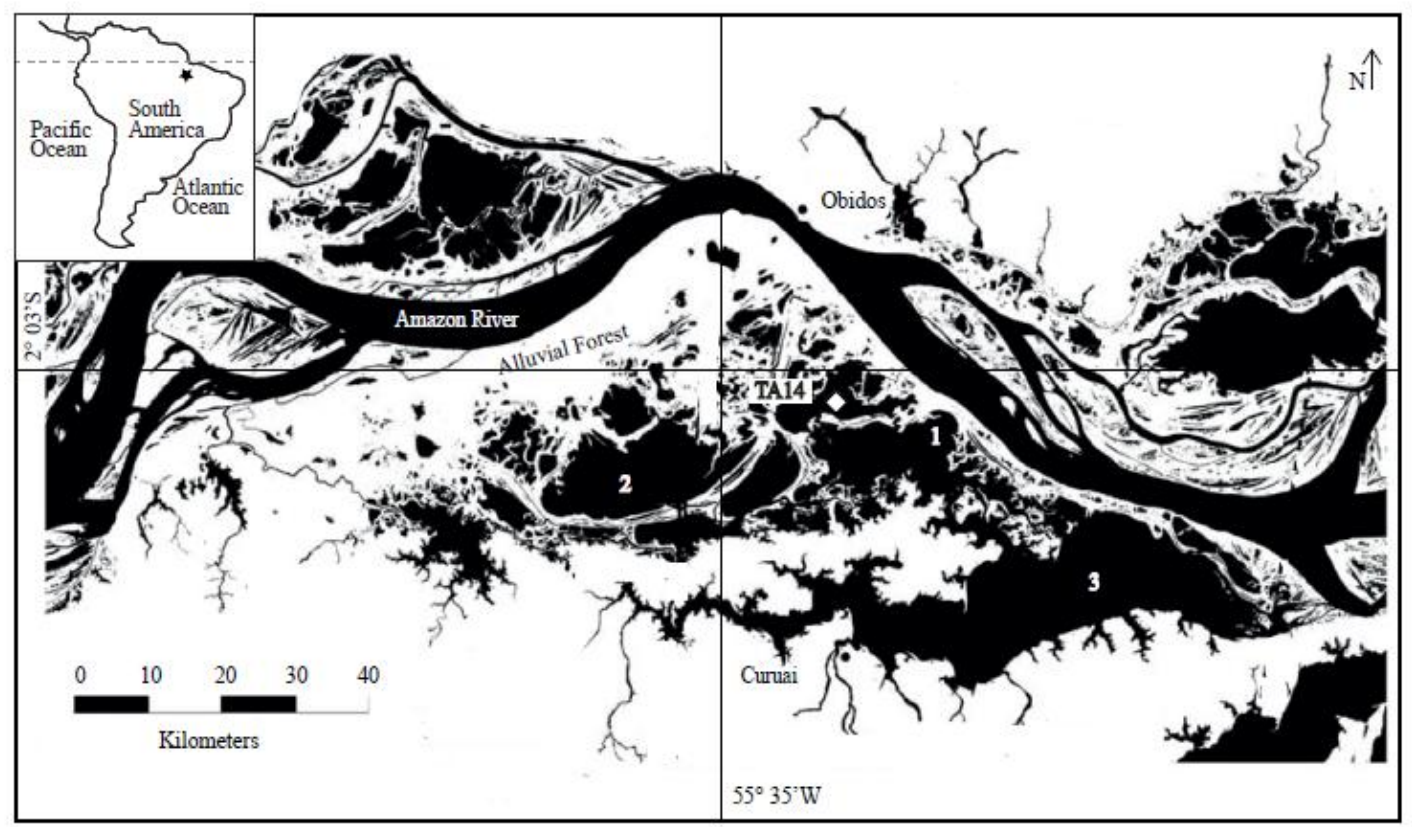


Figure 2

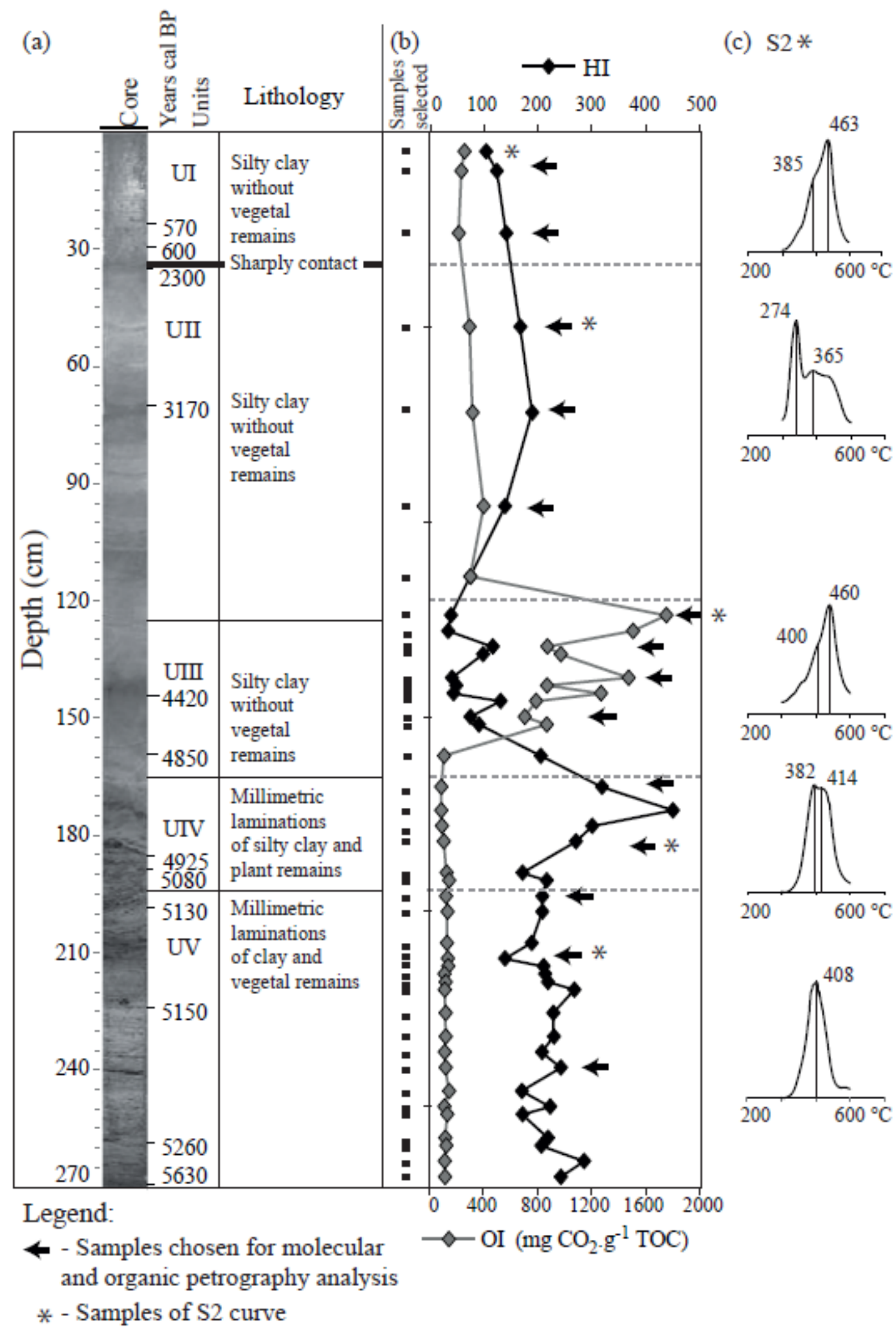


Figure 3

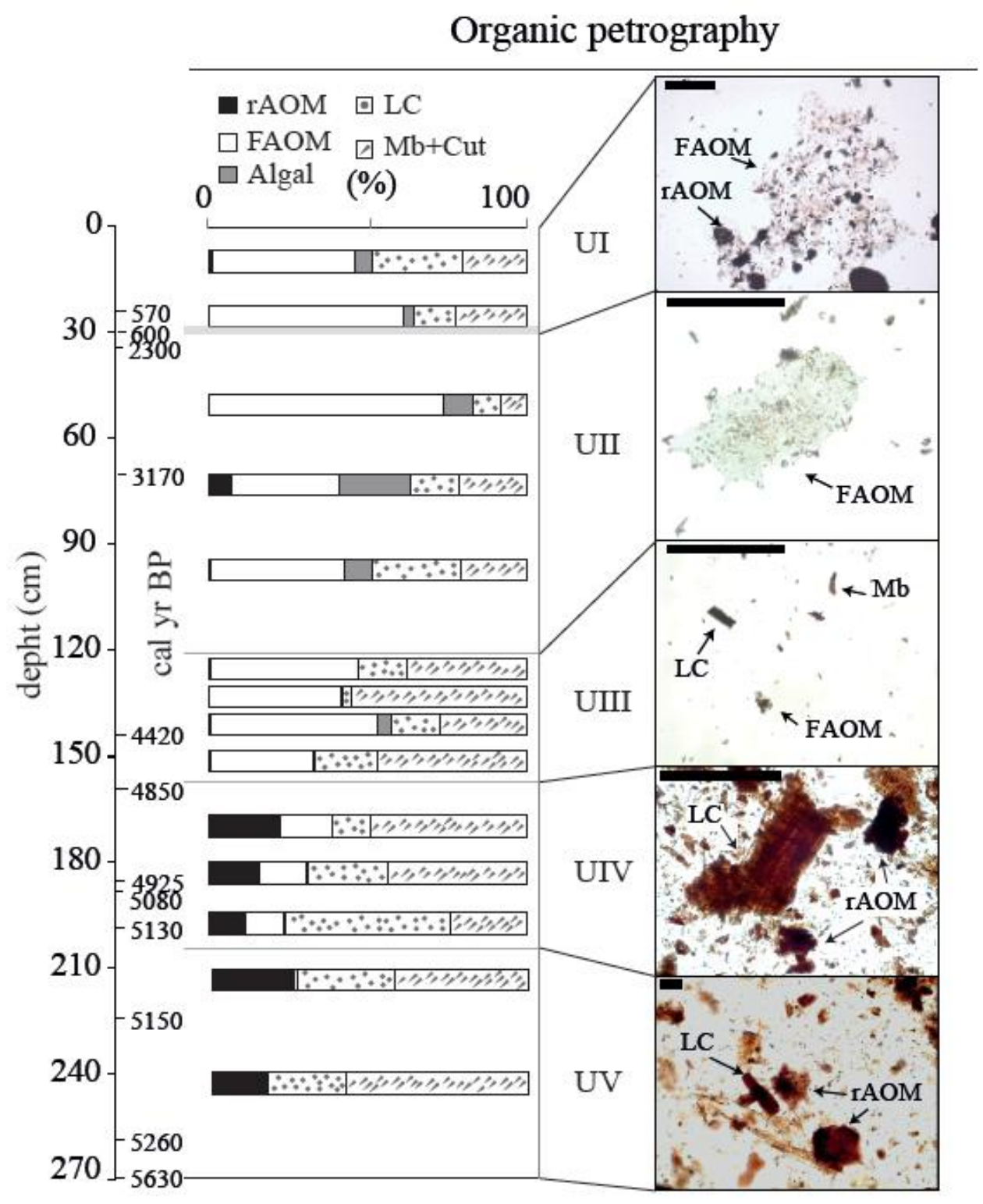


Figure 4

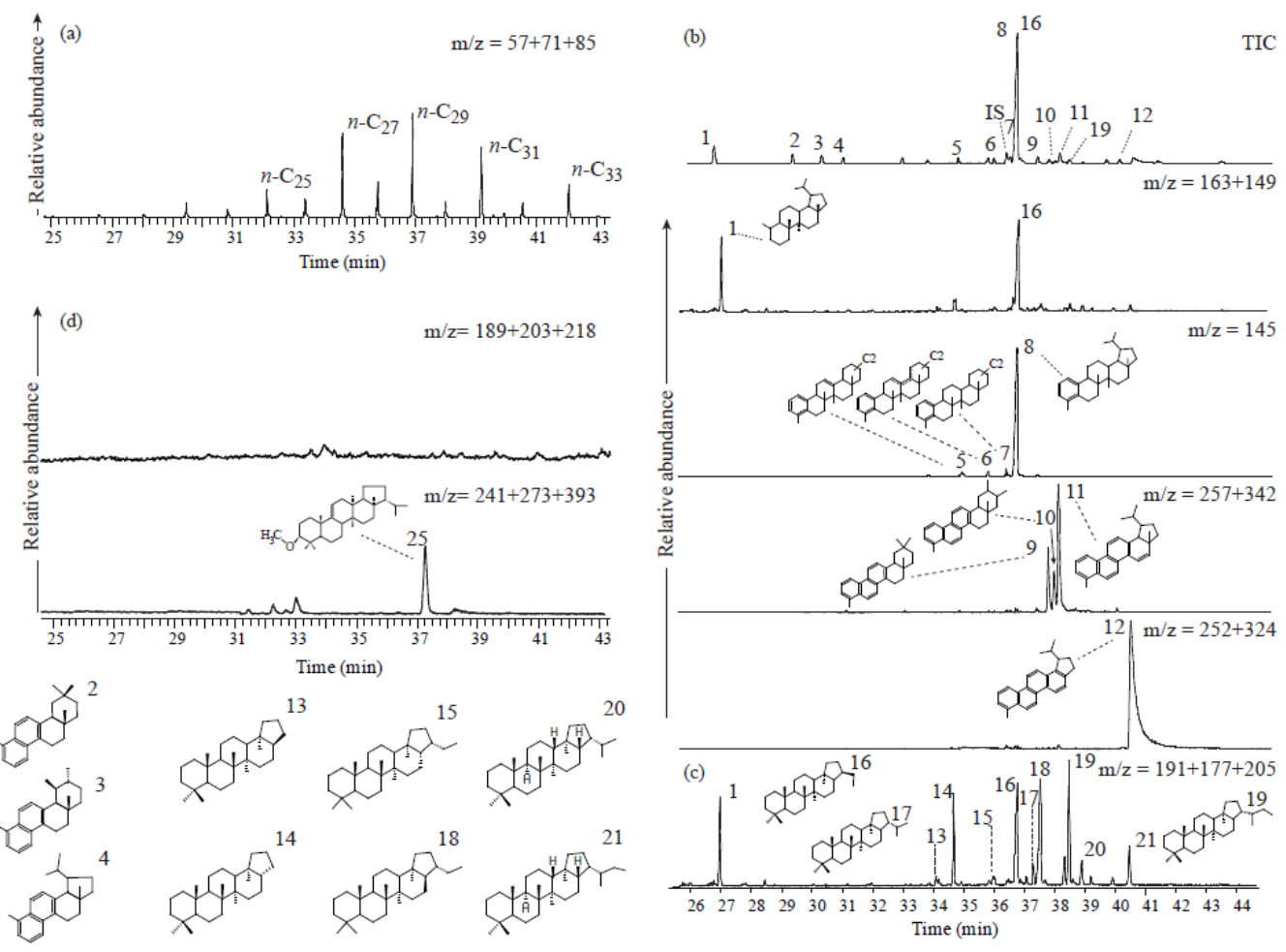


Figure 5
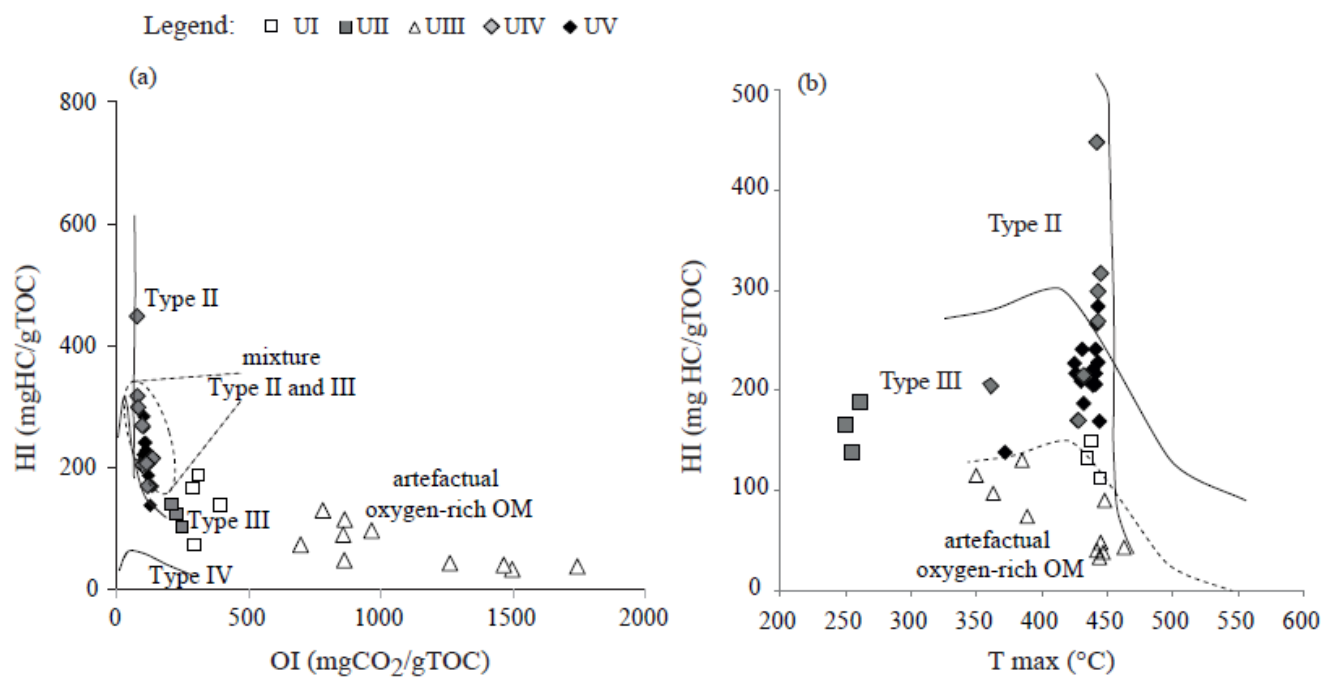
Figure 6

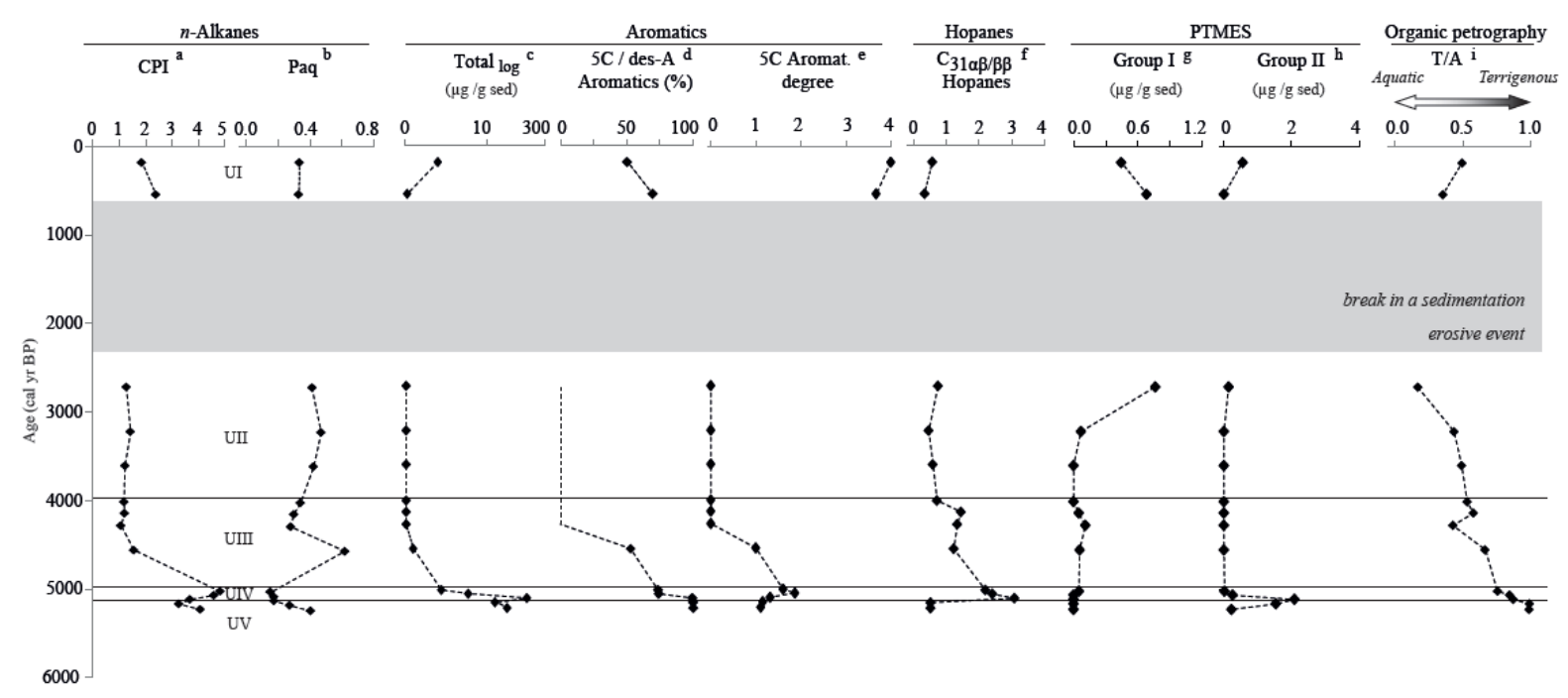




\section{Highlights}

- The aim was to characterize the land cover dynamics in the Curuai Floodplain.

- Obtained a $270 \mathrm{~cm}$ core that records the last $5600 \mathrm{cal} \mathrm{yr} \mathrm{BP.}$

- A multi-proxy approach revealed five distinct periods.

- Sedimentary OM origin alternated between land-derived soil and alluvial vegetation. 